3

4

5

6

7

8

9

\title{
Seismic Geomorphology of a Late Cretaceous Turbidite Channel system in Deepwater Kribi/Campo sub-basin, offshore Cameroon
}

Boris Gouott Secke Bekonga ${ }^{1}$, Mbida Yem ${ }^{1}$, Joseph Quentin Yene Atangana ${ }^{1}$, Eric Pierre Nkoa $\mathrm{Nkoa}^{2}$, Serge Edouard Angoua Biouele ${ }^{2}$, Yakufu Niyazi ${ }^{3}$, Ovie Emmanuel Eruteya ${ }^{4}$.

${ }^{1}$ University of Yaoundé I, Faculty of Science, Department of Earth Sciences, P.O. Box: 812, Yaoundé, Cameroon

${ }^{2}$ National Hydrocarbon Corporation (NHC), P.O. Box: 955, Yaoundé, Cameroon

${ }^{3}$ School of Life and Environmental Sciences, Deakin University, Warrnambool, Victoria 3280, Australia

${ }^{4}$ Department of Earth Sciences, University of Geneva, Geneva 1205, Switzerland

${ }^{*}$ Corresponding author: bsecke@yahoo.fr 


\section{Abstract}

In this study, a seismic reflection dataset and well-log data were integrated to investigate the geometry and internal configuration of a turbidite channel system within the Late Cretaceous interval of the deep-water Kribi-Campo sub-basin, offshore Cameroon. This interval is characterized by a well-developed submarine channel system consisting of an early and a latestage channel. Morphologically, the submarine channel system has a northeast-southwest trend and is U-shaped in cross-section with a length of $56 \mathrm{~km}$ within the study area. The early-stage channel has a relatively straight morphology and varies in width and depth from 3 to $5 \mathrm{~km}$ and 89 to $197 \mathrm{~m}$, respectively. However, the late stage of the channel is characterized by a narrower ( 1 to $3 \mathrm{~km}$ ) and shallower (41 to $103 \mathrm{~m}$ ) incision, with sinuous morphology carved into the early channel infill. The changing interaction of differential tectonic subsidence, relative sea level, source sediment supply and slope gradient change are considered to be the major control on the geometry and internal characteristics of the submarine channel system. Sag subsidence during the Campanian led to basin deepening and the widespread development of basinal sediments as submarine fans and promotion of submarine channel system development. The filling of the channel system occurred during a long-term Maastrichtian relative sea level rise, punctuated by falls in relative sea level. Sand appears to have been fed to the channel system by the palaeo-Sanaga and palaeo-Nyong Rivers, with sand rich aprons developed were these rivers debouched into the study area. The early stage of the submarine channel is dominated by coarse-grained sediments in the southwest and fine-grained sediments in the northeast, while the late-stage channel is mainly filled with fine-grained sediments. The presence of coarsegrained sediments occur within the submarine channel axis downstream represents a potential for hydrocarbon reservoirs with enhanced petrophysical qualities due to a low depositional gradient. The geomorphological analysis of this ancient submarine channel system along the western African margin, as presented in this study, has broad implications in the understanding of the distribution of deep-water sediments with potential for hydrocarbon exploration in the region.

65

Keywords: 3D seismic, Seismic geomorphology, Turbidity Channel, Kribi-Campo sub-basin, Offshore Cameroon. 


\section{Introduction}

Deep-water turbidite channel systems are important submarine features formed by the erosion, diversion, and deposition of turbidity currents and other sediment loads and flows (Shepard, 1981; Peakall and Sumner, 2015; Chiang et al., 2020; Tek et al., 2021). Submarine channels are a vital component of ancient and modern deep-water settings and play an essential role in transporting sediments into the deep-sea (Stow and Mayall, 2000; Normark and Carlson, 2003; Posamentier and Kolla, 2003; Mayall et al., 2006; Posamentier and Walker, 2006; Shanmugam, 2006; Gamboa et al., 2012; Chima et al., 2019). Deep-water sediments within these channels record paleoclimatic and oceanographic information and are crucial in understanding the geological evolution of sedimentary basins (Marsset et al., 2009; Jobe et al., 2015; Picot et al., 2016; Hansen et al., 2017; Niyazi et al., 2018; Chima et al., 2020). Deepwater sediments transported by submarine channels are a potential host for significant hydrocarbon accumulations (Mayall et al., 2006; Wynn et al., 2007; Weimer et al., 2007; Di Celma et al., 2010; Jobe et al., 2015).

Previous studies have focused on the origin, depositional processes and factors controlling the emplacement, composition, and morphological evolution of submarine channels (Kane et al., 2008; Babonneau et al., 2010; Covault et al., 2014; Li and Gong, 2016; Sylvester and Covault, 2016; Li et al., 2020). Also, the increased availability of marine geophysical data has significantly improved the understanding of the architecture, morphometry and processes leading to submarine channel development (Abreu et al., 2003; Deptuck et al., 2003, 2007 and 2012; Kolla et al., 2007; Sylvester et al., 2011; Mitchell et al., 2021). High-resolution 3D seismic reflection data have allowed the geomorphologic character of these deep-water systems to be unraveled, and their implications for the hydrocarbon exploration (Deptuck et al., 2007; McHargue et al., 2011; Jobe et al., 2011; Qin et al., 2016; Covault et al., 2019; Mitchell et al., 2021).

Submarine channels in the deep-water basins offshore West Africa (e.g., Niger Delta, Congo, and Gabon) are well studied using high-quality seismic reflection and borehole datasets provided by hydrocarbon exploration companies operating in these regions (Abreu et al., 2003; Lin et al., 2014; Jolly et al., 2015; Huang, 2018; Chima et. al., 2019 and 2020; Chen et al., 2021). Hydrocarbon reservoirs (e.g., Okume, Oveng, Ebano and Ceiba oil fields) in similar settings have been found in the Santonian-Maastrichtian turbidite sediments in the offshore of Equatorial Guinea (Dailly, 2002; Sterling, 2010). Also, along the Cameroonian margin, various Miocene channels, and fan system across the Douala/Kribi-Campo Basin are hydrocarbon-rich (SPT, 1995; Loule et al., 2018).

The Douala/Kribi-Campo Basin is one of a series of continental shelf basins extending in West Africa from the edge of the Niger delta in Cameroon to the Walvis ridge near the Angola-Namibia border. The Kribi/Campo sub-basin, which is a component of the northern Douala/Kribi-Campo Basin, hosts the South Sanaga and Kribi oil fields in deep-water turbidite sediments (Pauken et al., 1991; Pauken, 1992; Nguene et al., 1992; Ackerman et al., 1993; Tamfu et al., 1995; Brownfield and Charpentier, 2006; Ndonwie, 2007). However, in contrast to the well-studied submarine channels and their implications for hydrocarbon exploration in the West African basins (e.g., Niger Delta, Congo, and Gabon), those in the Kribi/Campo subbasin are poorly understood in terms of their architectural elements, morphological variations and factors controlling the distribution of sands (see Iboum et al. 2016; Loule et al., 2018; Yugye et al., 2021). 
Therefore, this study is aimed at investigating and analyzing the geometry and internal configuration of a newly mapped well-developed Late Cretaceous submarine channel system in the Kribi-Campo sub-basin. This was achieved through analysis of a 3D seismic reflection data and borehole data. The findings from this study extend the understanding of the architectural and morphological evolution of deep-water channel systems in the Kribi-Campo sub-basin and elsewhere with similar settings and its implication deep-water hydrocarbon prospectivity.

\section{Geological Setting}

The study area is located along the continental slope of the Kribi-Campo sub-basin approximately $40 \mathrm{~km}$ off the coast of Cameroon (Fig. 1). It is situated in water depths ranging from 600 to $2000 \mathrm{~m}$ (Fig. 1). The Douala/Kribi-Campo Basin is divided into two sub-basins, namely the Douala sub-basin in the northern part and the Kribi-Campo sub-basin in the south (Fig. 1). The southern sub-basin, which was investigated in this study, covers an area of 6150 $\mathrm{km}^{2}$. The Kribi-Campo sub-basin covers an area of $45 \mathrm{~km}^{2}$ onshore and stretches NNE-SSW on continental margin, between $2^{\circ} 10^{\prime}$ and $3^{\circ} 20^{\prime} \mathrm{N}$, and $9^{\circ}$ and $10^{\circ} 30^{\prime} \mathrm{E}$ (Fig. 1).

The evolution of the Kribi-Campo sub-basin is closely related to the opening of the South Atlantic Ocean following the rifting of South America and Africa (Rabinowitz and Labrecque, 1979; Beglinger et al., 2012). The evolution of the Douala/Kribi-Campo Basin can be divided into four stages (Fig. 2): a pre-rift stage (Proterozoic to late Jurassic), syn-rift stage (late Jurassic to early Cretaceous), transitional stage (middle to late Aptian) and a post-rift stage (Albian to recent) (Pauken, 1992; Lawrence et al., 2002; Brownfield and Charpentier, 2006; Ntamak-Nida et al., 2010; Sterling, 2010; CGG Robertson, 2015; Brownfield, 2016; Lawrence et al., 2016; Mienlam et al., 2021). The pre-rift stage consists of Precambrian arkosic sandstones and conglomerates (Nguene et al., 1992). Brownfield (2016) show that this section occurs in the deeper offshore parts of the Douala/Kribi-Campo Basin. On the onshore part, there is no evidence of pre-Cretaceous sediments either in wells or at outcrops. The syn-rift stage is a thick sequence, consisting of massive fluvial and alluvial sandstones and conglomerates of early Cretaceous age, with laterally continuous units that could potentially be a reservoir target (Ntamak-Nida et al., 2008). These pass upward into dark laminated lacustrine shales that may have source rock potential. The transitional stage represents the onset of seafloor spreading (Brownfield, 2016; Mienlam et al., 2021). During this stage, the deposition of evaporite units occurred (Fig. 2). These deposits were penetrated in Kribi-Campo offshore sub-basin throughout the Kribi Marine-1 (Nguene et al., 1992; Pauken, 1992; Lawrence et al., 2002; Meyers et al., 1996). Moreover, other salt units have been recognized on the continental-shelf in the study area using seismic data (Loule et al., 2018; Mienlam et al., 2021). During the postrift stage, a major regional drift unconformity developed across the Douala Basin in the early Senonian, marking the complete cessation of lithospheric extension and the onset of the continental divergence with the development of the passive margin (Meyer et al., 1996; Rosendahl, 1999; Sterling, 2010; Mvondo, 2010; Le, 2012). The drift unconformity is characterized by the discordant erosion of early Cretaceous sequences along the uplifted eastern margin of the Kribi-Campo sub-basin. The footwall of the southern Kribi Fracture Zone (KFZ) was subjected to up to $1 \mathrm{~km}$ of uplifting (Sterling, 2010). The break-up unconformity lies between 92 and $86 \mathrm{Ma}$, and it is estimated that a minimum of $660 \mathrm{~m}$ thick sediments were eroded (Turner, 1999; Fusion, 2002) (Fig. 2). This Santonian tectonic event with its associated uplift led to the deposition of thick late Cretaceous clastics characterized by slope and basin floor fans containing multiple channel complexes (Sterling, 2010; Le, 2012 and 2021). A series of eustatic lowstands during the Campanian-Maastrichtian and the Santonian uplift facilitated the episodic 
transport of major clastic sequences across the relatively narrow shelf into the deeper basin to the west (i.e., in the study area) (Fig. 2). Sterling (2010) estimated that an excess of 1500-2000 $\mathrm{m}$ of Senonian deep-water clastic sediments were deposited in the study area during this phase of post-rift sedimentation.

Post-rift thermal subsidence of the Kribi-Campo sub-basin began to wane during the Tertiary with the accommodation of up to 2400-2700 m thick wedge of deep-water clastic sediments in the study area. The basin continued to subside throughout the Tertiary. Subsidence was interrupted by an Oligocene tectonic event, which led to the uplift of the post-rift sediments and the development of a regionally extensive unconformity throughout equatorial West Africa (Turner, 1999). This Oligocene unconformity was underpinned by igneous intrusions during lithospheric thinning and volcanism that was associated with the formation of Cameroon volcanic arc in the Neogene (Seranne et al., 1992).

The post-rift sequence in the study area is characterized by sand-rich turbidity channel belts and basin floor to toe-of-slope fans (Wornardt, 1999; Sterling, 2010; Le, 2012; Iboum et al., 2016; Loule et al., 2018; Yugye et al., 2021) (Fig. 2). In the more proximal settings (i.e., east of Kribi-Campo High), there are multiple submarine incisions of several kilometres wide and some amalgamated cut-and-fill submarine channel complexes downslope and parallel to present-day shelf-break for most of the Paleocene section (Wornardt, 1999; Le, 2012; Iboum et al., 2016). The late Eocene-early Oligocene tectonic event facilitated a relative sea-level fall, responsible for the widespread erosion and non-deposition in the deep-water of Douala Basin (Wornardt, 1999; Helm, 2009; Mvondo, 2010; Iboum et al., 2016; Ngo et al., 2018; Le, 2021) (Fig. 2). Following this period of non-deposition, a thick Miocene-Pliocene clastic wedge originating from a combination of multiple continental paleo-river drainage systems (e.g., Proto-Sanaga, proto-Nyong and proto-Ntem River systems), prograded across the narrow shelf area (Sterling, 2010; Le, 2012). Sediments prograded down the steeply dipping fault margin into the offshore Kribi-Campo sub-basin and deposited a thick sequence of sand-rich turbiditic channels (Sterling, 2010; Le, 2012).

\section{Dataset and Methods}

\subsection{Dataset}

The dataset analyzed in this study consists of a high-resolution 3D seismic reflection survey and borehole data from the Kribi-Campo Sub-basin offshore Cameroon (Fig.1).

\subsubsection{Seismic data}

The 3D seismic survey is a pre-stack time-migrated (PSTM) dataset that covers an area of about $1500 \mathrm{~km}^{2}$ in water depths ranging between $600 \mathrm{~m}$ and $2000 \mathrm{~m}$ (Fig.1). It was acquired using 10 streamers, with a $12.5 \mathrm{~m}$ group interval. The separation between the streamers was $100 \mathrm{~m}$ and spatial resolution was $25 \times 25 \mathrm{~m}$. It includes 1581 in-lines and 2051 crosslines with lines spacing of $25 \mathrm{~m}$ and a seismic recording sampling interval of 2 milliseconds two-way travel time (TWT). The seismic survey was processed as a zero-phase at the seabed and displayed using the Society of Exploration Geophysicists (SEG) normal polarity (Brown, 2004). Hence, a positive event represents a downward increase in acoustic impedance (red, yellow, or orange reflection on seismic sections), and a negative event represents a downward decrease in acoustic impedance (blue reflection on seismic sections). The seismic dataset reaches $6.6 \mathrm{~s}$ TWT. A dominant frequency of $17 \mathrm{~Hz}$ was estimated for the Upper Cretaceous and $45 \mathrm{~Hz}$ in the Cenozoic resulting in a vertical resolution $(\lambda / 4)$ of $\sim 28 \mathrm{~m}$ and $\sim 10 \mathrm{~m}$, respectively (Le, 2012 and 2021). 


\subsubsection{Well data}

The study integrates well log data (gamma rays, resistivity, density, neutron, and sonic total depth of $4090 \mathrm{~m}$ below the seafloor corresponding to a stratigraphic interval ranging between Albian to Recent. The wells cover the interval of interest and biostratigraphic data were not available. Formations tops of the two wells and the checkshots data for the well W1 were used to correlate the seismic and borehole data. Well data from the W1 wellbore were used to constrain the lithology and ages of the different horizons and deposits interpreted, as well as average velocity for the W1 $(2400 \mathrm{~m} / \mathrm{s})$.

\subsection{Methods}

\subsubsection{Seismic stratigraphy}

The approach used here consists of the seismic interpretation of ten horizons (KC-1 to KC-9, and the seafloor) (Fig. 2). These seismic horizons were tied to the well W1 using the checkshot data and the interval of interest was divided into two main seismic units based on the recognition of reflection termination patterns such as onlap, erosional truncations, seismic facies/configuration, and vertical stacking patterns (Mitchum et al., 1977). In the present study, submarine channel systems and submarine fans were identified based on seismic criteria and 3D geomorphology (e.g., Posamentier and Kolla, 2003; Loule et al., 2018).

\subsubsection{D Seismic geomorphology}

Identification and mapping of the submarine channels were achieved using a 3D seismic geomorphological approach (Zeng et al., 1998; Zeng, 2001; Posamentier, 2003; Brown, 2004; Kolla et al., 2007; Niyazi et al., 2018; Chima et al., 2020). Seismic attributes such as RMS (Root Mean Square) amplitude and variance, were extracted along the horizons to illuminate and visualize the channels as well as to characterize geological anomalies that are isolated from background features by means of an amplitude response (Taner, 2001). The RMS amplitude maps are mathematically computed by squaring individual traces over a defined time window (Brown, 2004; Omosanya and Alves, 2013). They boost high amplitudes in an interpreted interval, allowing the amplitude reflections related to sands or other high-density materials within channels to be discriminated from their associated low amplitude chaotic facies (Brown, 2004; Omosanya and Alves, 2013; Chima et al., 2019). Variance is the direct measurement of the dissimilarity of seismic traces. Variance maps convert a volume of continuity into a volume of discontinuity, highlighting structural and stratigraphic boundaries (Brown, 2004). Features identified in the variance time slices were also used as additional verification for the seismic sections. For example, the channels on seismic sections are erosional features characterized by onlapping on their margins and by contrasting amplitudes between their fill and adjacent overbank deposits (Gamboa et al., 2012; Harishidayat et al., 2018; Omosanya et al., 2019). In this study, we generated a series of RMS and variance time slices to analyze the evolution of the submarine channel system during different periods.

\subsubsection{Quantitative analysis of sub-marine channel}

In addition to classical seismic stratigraphic methods, the quantitative analysis of the seismic geomorphology of submarine channels was performed following the methodologies proposed by Deptuck et al. (2007), Gamboa and Alves (2015), Qin et al. (2016), Hansen et al. (2017), Harishidayat et al. (2018) and Zhao et al. (2018). Morphometric parameters such as width (defined as the distance between the banks of the channel system), depth (defined as the 
depth of the channel from their overspill points to their bases), and depth of the channel thalweg (defined as a middle point of the channel walls and the lowest point of the erosional surface), were measured in cross-sectional seismic profiles (Fig.3). These seismic profiles are perpendicular to their axial lines and located at an interval of $1 \mathrm{~km}$ (average), down-dip. The zero point was defined as the northernmost limit of the channel. The thalweg depth (in TWT) was converted to depth (in m) using the interval velocity of $2400 \mathrm{~m} / \mathrm{s}$ (calculated from the checkshot data of well W1) for the Late Cretaceous sediments. Furthermore, the channel gradient was calculated based on changes in thalweg depth along the length of the channel. For this purpose, the thalweg depth was measured on each profile along the channel. Subsequently, the paleo-topography on which the channel developed was divided into windows with different average gradient segments depending on the magnitude of the thalweg depth variations on the profiles. Vertical and horizontal distances (the vertical distance must be converted into depth profiles) between the starting and ending points of these windows were measured. The final gradients according to the arc tangent function were measured (Deptuck et al., 2007; Gamboa and Alves, 2015; Qin et al., 2016; Harishidayat et al., 2018; Zhao et al., 2018).

\section{Results and interpretation}

\subsection{Seismic stratigraphy of the study area}

The interpreted ten horizons (KC-1 to KC-9 and the seafloor) are used to describe the seismic stratigraphic framework of the study area (Fig. 4). KC-1 to KC-9 horizons correspond to the Top Albian, Santonian, Campanian, Maastrichtian, Paleocene, Eocene, lower Miocene, middle Miocene, late Miocene, respectively (Le, 2012; Iboum, 2016). The interval of interest in the study area is bounded by the KC-3 and KC-4 horizons at the base and top, respectively. This interval is characterized by distinctive seismic facies of the Campanian-Maastrichtian Logbaba Formation (Fig. 4).

The KC-3 is located at approximately $4900 \mathrm{~ms}$ TWT and is characterized by a highamplitude peak reflection with good continuity (Fig.4). This horizon is characterized the Kribi High area and defines the base of an agraddational pattern and laterally migrating which correspond to a possible turbidite fan system which extends from the east to the southern half of the study area (Fig. 5). Based on its seismic character and according to Iboum et al., 2016; the surface KC-3 corresponds to an unconformity in the study area which progressively shows greater truncation of underlying sequences toward the upper slope (Fig. 4). The isochore map shows values ranging from $-3700 \mathrm{~ms}$ upstream to $-5100 \mathrm{~ms}$ downstream (Fig. 6a). These two extreme values correspond respectively to a high and low topographic area on either side of the study area. It is separated by a steep slope on the side of the continent that becomes increasingly soft towards the seabed. The horizon KC-4 is located at approximately $4600 \mathrm{~ms}$ TWT and is a peak reflection with high amplitude. The horizon is characterized by downlaps onto an erosional surface and marks the change from a low frequency sequence below to a higher frequency sequence above (Fig. 5). The isochore map shows values ranging from $-3200 \mathrm{~ms}$ to $-4800 \mathrm{~ms}$, respectively at two downstream and upstream ends of the sub-basin (Fig. 6b). The contours lines of isochore map have a preferred NE-SW direction and have a folded shape in the central part (Fig. 6b).

The surface KC-4 is incised by a NE-SW trending channel and covers the Kribi High in the east (Figs. 4a and 4b). On the basin floor at the more distal end of the depositional system (i.e., around P1), the surface marks the base of the relatively low-amplitude Tertiary package (Fig. 4a). This contrasts with the underlying Cretaceous sequences which in cross-section are more channelized and display higher amplitudes (Fig. 5). The thickest area reaches $1560 \mathrm{~m}(\mathrm{Vp}$ $=2400 \mathrm{~m} / \mathrm{s}$ ) in the east, and the average thickness of the unit is $1080 \mathrm{~m}$ (Fig. 6c). 
The interval of interest in this study (Campanian-Maastrichtian succession) has been divided into two seismic sub-units: seismic unit 1 (SU1) and seismic unit (SU2) based on the differences in the internal seismic reflection configurations (Fig. 5). SU1 consists of sub parallel and aggradational reflections (Fig. 5). SU 1 is generally characterized by low amplitudes reflectors with limited occurrence of high amplitude reflectors, with maximum thickness in the east (Fig. 5). The high amplitude seismic facies display an aggradational pattern with parallel and continuous reflectors displaying fan-shaped geometry (Table 1, Fig.5). SU2 forms the uppermost unit in the Late Cretaceous, and consists of low to high amplitude, sub-parallel and continuous reflectors. A large incision occurs within this unit, which is interpreted as a submarine channel, characterized by high-amplitude reflections at its base (Table 1, Fig. 5).

\subsection{Late Cretaceous submarine channel}

\subsubsection{Channel infill: distribution of seismic facies and interpretation}

Five seismic facies (SF1 to SF5) were identified in the study interval and can be interpreted to represent five specific depositional settings (Table 1).

SF1 consists of high amplitude, chaotic reflections confined within a V- or U-shaped erosional surface in cross section (Figs. $7 \mathrm{~b}$ and 7c). In plan view, SF1 is expressed as a more linear morphology compared to SF2 (Fig. 9). It occurs at the basal lags of the early-stage channel. This facies is interpreted as coarse-grained sediments deposited in the submarine channel axis (Mayall et al., 2006; Gee et al., 2007) (Fig. 9).

SF2 consists of low-amplitude, parallel reflections with a U- or V-shaped external geometry (41-103 m depth, 1-3 km wide) in cross section (Figs. 7) and is expressed as a narrow and has a sinuous morphology in plan view (Fig. 9). This facies is comparable to "mud-filled bypass channels" of Wynn et al. (2007), or "last-stage channel-fills" of Janocko et al. (2013). This facies is interpreted as clay-prone channel fills that may record earlier channel bypassing (of coarse-grained sediments) and later abandonment (deposition of fine-grained sediments).

SF3 is composed of low-amplitude, continuous seismic reflections and occurs in the unit containing the submarine channel (Figs. 7b and 7c; Table 1). It occurs the entire seismic volume on the map view outside the submarine channel system. in the map view (Fig. 9). SF3 can be interpreted as pelagic sediments (Fig. 9); the facies is similar to pelagic deposits, as observed in other studies (e.g., Su et al., 2015; Gong et al., 2016).

SF4 is comprised of high-to low-amplitude, convergent reflections that show a broadly wedge-shaped geometry in cross section (Figs. $7 \mathrm{~b}$ and $7 \mathrm{c}$ ). This facies is widely recognized elsewhere and interpreted to represent levees deposits (Table 1) formed of fine-grained sediments from the overbanking of turbidity currents (e.g., Posamentier and Kolla, 2003; Deptuck et al., 2003; Catterall et al., 2010; Janocko et al., 2013).

SF5 is characterized by high-amplitude reflection displaying an aggradational pattern in cross-section and it is located below the submarine channel system in sub-unit SU1 (Fig. 5; Table 1). In map view, it occurs the SE part in the study area (Figs. 9c and 9d). This facies correspond to the sand body which can be interpreted to fan deposits, and it is like those observed and described by Twichell et al. 2009.

\subsubsection{Internal architecture and geometry of the submarine channel}

The submarine channel observed in unit SU2 is U-shaped in cross-section (Fig. 7). It has two vertically stacked channels that developed at different stages. The late-stage channel lies completely within the early-stage channel, and both exhibit distinct seismic reflection characteristics (Figs. $7 \mathrm{~b}$ and $7 \mathrm{c}$ ). The late stage of the channel is characterized by seismic facies SF1 and SF2. Seismic facies SF1 is mainly located along the thalweg of the early stage of the 
channel. It occurs at the base of submarine channel analyzed in this study (Figs. $7 \mathrm{~b}$ and $7 \mathrm{c}$ ). Seismic reflection characteristics of this facies is like those of the channel axial deposits described by Deptuck et al. (2003), Mayall et al. (2006) and Catterall et al. (2010). SF2 is usually confined at the flanks of the channel (Figs. 7b and 7c). Specifically, this facies is located on the side of the late-stage channel fill (Figs. 7b and 7c). According to the seismic reflection characteristics described by Mayall et al. (2006) and Gee et al. (2007) (Figs. 7b and 7c; Table 1). The late stage of the channel is dominated by the SF2 facies. In addition, SF1 and SF2 are inside the channel system and the seismic facies SF3 and SF4 are located outside of the system (Figs. 7b and 7c). SF3, mainly occurs in the unit containing the submarine channel. SF4 is seen outside of the early channel belt and occurs only locally (Fig. 7; Table 1). These reflections typically dip away from the channel axis and decrease in amplitude away from the channel axis (Fig. 7b).

To analyze the evolutionary history and infilling of the submarine channel system, unit SU2 was divided into four intervals below the top of the channel that corresponds to the KC 04 horizon (Figs. 7a and 8). The well-log in the vicinity of the submarine channel system indicates that the thickness between the top and base of the channel is approximately $130 \mathrm{~m}$ (Fig. 8a). The gamma-ray motif shows a medium serrated peak and, in some places, a low gamma-ray peak. The well-log petrofacies of this submarine channel consists of the clay interbedded with layers of sands (Fig. 8a). The early-stage channel is visible on all the maps and is characterized by relatively linear morphology (Fig. 9). The channel is $56 \mathrm{~km}$ long and 3-5 km wide (Fig. 9), with an incision depth of 89-197 m (Fig. 10). In contrast, at the late stage, the channel could only be imaged in the upper two slices (Figs. 9a and 9b). The RMS and variance values also characterize the channel fills in the horizon slices. The high RMS amplitudes and low variance occur within the sub-marine channel axis. The channels also locally incise areas of high RMS amplitudes and low variances, characterized by lobate geometry outside the channel axis (Fig. 9). The low RMS values and high variances are observed in the northeast part of the channel while the high RMS values and low variances are observed in the southwest part of the channel (Fig. 9d). This high amplitude RMS channel fill observed in the horizon slice corresponds in cross section to seismic facies SF1 and the low amplitude RMS fill corresponds to seismic facies SF2. The late-stage channel is narrower and has a sinuous morphology and is located within the early- stage channel, which is wider and has a straight shape (Fig. 9). The dimension of the late- stage channel is $1-3 \mathrm{~km}$ wide, the length is about $56 \mathrm{~km}$ (Fig. 9), and the depth vary from 41 to $103 \mathrm{~m}$ (Fig. 10).

\subsubsection{Morphometric analysis of the submarine channel}

There is a significant morphological variation along the submarine channel system (Figs. 9 and 10). In the northeastern portion, near the sediment source area, the channel morphology varies considerably when compared to the southwestern portion which is characterized by significantly greater width and smaller depth (Fig. 10).

The depth profile of the early channel thalweg shows an exponential trend and is divided into three intervals $(1,2$, and 3$)$ that correspond to three segments $(\mathrm{x}, \mathrm{y}$, and $\mathrm{z})$ based on the channel gradient variations (Fig. 11a; Table 2). The gradient of the early-stage channel is $2.64^{\circ}$ in the first segment (Fig. 11a). Between $12 \mathrm{~km}$ and $33 \mathrm{~km}$, in segment y, the channel gradient decreases to $2.02^{\circ}$. In the rest of the channel, segment $\mathrm{z}$, the channel slope decreases between 33 and $44 \mathrm{~km}$, and reaches its lowest value of $0.40^{\circ}$ (Fig. 11a).

The channel width also displays three intervals. It varies between $3224 \mathrm{~m}$ and $4677 \mathrm{~m}$ for the early-stage channel to $1094 \mathrm{~m}$ and $2865 \mathrm{~m}$ for the late-stage channel in the first $12 \mathrm{~km}$ of interval 1(Fig. 11b; Table 2). In interval 2, channel width increases to a maximum value of $5573 \mathrm{~m}$ at $17 \mathrm{~km}$ for the early channel to $3802 \mathrm{~m}$ at $18 \mathrm{~km}$ for the late-stage channel. This 
increasing trend is followed by a decrease in the width of the late channel to its lowest value of $2993 \mathrm{~m}$ at $27 \mathrm{~km}$. In the interval 2, between 27 and $32 \mathrm{~km}$ show an increase in channel width with slight variation. In interval 3, between 33 and $44 \mathrm{~km}$, the width of the early-stage channel varies from $3830 \mathrm{~m}$ to $4260 \mathrm{~m}$. The width of this late-stage channel has a decreasing trend and varies between $3300 \mathrm{~m}$ to $1115 \mathrm{~m}$ (Fig. 11b).

The depth profile of the early-stage channel thalweg also shows remarkable variation along the channel path (Fig. 11a), correlating with the variation in the depths of the early channel (Fig. 11c). A plot of channel thalweg versus along channel distance also revealed three intervals (Figs. 11a and 11c; Table 2). The first interval $(0-12 \mathrm{~km})$ begins with the lowest value of channel depth to the northeast of the seismic survey (Fig. 11c), followed by an increase to $170 \mathrm{~m}$ at $9 \mathrm{~km}$ in the early channel (Figs. 11c). The depth of the early-stage channel in this interval ranges from $89 \mathrm{~m}$ to $171 \mathrm{~m}$. In interval 2, between 12 and $33 \mathrm{~km}$, the channel depth begins with an increase from $109 \mathrm{~m}$ at $12 \mathrm{~km}$ to $179 \mathrm{~m}$ at $15 \mathrm{~km}$ (Fig. 11c). Then, the channel depth decreases to its minimum value of $87 \mathrm{~m}$ at $24 \mathrm{~km}$, before fluctuating by increasing between $153 \mathrm{~m}$ and $183 \mathrm{~m}$ for the rest of the interval (Fig. 11c). The third interval (33 to 44 $\mathrm{km}$ ) has the highest value of early channel depth, $197 \mathrm{~m}$ at $35 \mathrm{~km}$ (Fig. 11c). In this interval, the depth of the early-stage channel begins with an increase followed by a decreasing trend after reaching its maximum depth. The depth fluctuates between $112 \mathrm{~m}$ and $197 \mathrm{~m}$.

The width/depth ratio of the early-stage channel varies from 18 to 54 (Fig. 11d; Table 2 ) in the three intervals along the channel. The first interval begins with a decrease in the ratio and fluctuates along the rest of the interval between 27 to 42 for the early-stage channel. The ratio fluctuates within interval $2(13$ and $33 \mathrm{~km})$, reaching its maximum value from 51 to 24 $\mathrm{km}$ before decreasing to its minimum value from 17 to $25 \mathrm{~km}$ in the early-stage channel. Between 33 and $44 \mathrm{~km}$, the width/depth ratio in interval 3 shows an increasing trend to the northeast of the study area, where it reaches 43 (Fig. 11d).

With respect to the late-stage channel, the channel depth in the first interval varies from $41 \mathrm{~m}$ to $79 \mathrm{~m}$. In the second interval, the depth of the late-stage channel starts with a decrease, followed by an increasing trend from $47 \mathrm{~m}$ to $97 \mathrm{~m}$ at $23 \mathrm{~km}$. The rest of the channel varies between $68 \mathrm{~m}$ and $98 \mathrm{~m}$ in depth. The depth in the third interval reaches a highest value of 103 $\mathrm{m}$ at $35 \mathrm{~km}$ (Fig. 11c). The depth profile of the late-stage channel starts with a decrease. The general trend of channel depths is downward in this interval and ranges from $103 \mathrm{~m}$ to $59 \mathrm{~m}$. The latter value corresponds to the northeastern edge of the submarine channel in the seismic volume (Figs. 10 and 11c).

The width/depth ratio of the late-stage channel varies from 17 to 51 (Fig. 11d; Table 2) in the three intervals along the channel. The first interval begins with a decrease in the ratio, followed by fluctuations along the remaining of the interval between 21 and 42 for the latestage channel. In interval $2(13$ and $33 \mathrm{~km})$, the late-stage channel reaches a maximum value of 54 at $18 \mathrm{~km}$ and a minimum value of 25 at $33 \mathrm{~km}$. Between 33 and $44 \mathrm{~km}$, the ratio shows a decreasing trend towards the northeastern edge, where it reaches a minimum value of 18 (Fig. 11d).

\section{Discussion}

\subsection{Controls on the evolution of the Cretaceous submarine channel system}

Submarine channels respond to sea-level change, sediment flux, tectonics, and climate, and have a significant impact on the sedimentary architecture of continental margins (Reading and Richards, 1994; Wu et al., 2018). Several factors can be suggested as the principal controls on the development of the Late Cretaceous submarine channel system in the study area. This encompasses tectonics, relative sea-level fluctuations, fluvial sediment supply, and slope 
gradient. Here, these factors are examined first in terms of whether and how they might have influenced the evolution of the submarine channel system.

\subsubsection{Influence of tectonic movement}

Most basins in the South Atlantic and West and Central Africa continued to evolve after the Lower Cretaceous rifting, often as a result of thermal subsidence (SPT, 1995). There was a major phase of regional deformation in the Santonian/early Campanian, probably related to the change in velocity and direction of African plate motion, coinciding with the progradation of oceanic spreading north of the Bay of Biscay (Binks and Fairhead, 1992). The continental shelf was exposed to large-scale erosion and there was sufficient sediment supply. A large amount of sediment was transported to the basin in deep-water, providing the material conditions for the development of gravity flow and forming the deep-water fan at the Campanian. Between the latest Cretaceous/earliest Tertiary, the West African margin may be uplifted, re-exposed and major erosion occurs with the development of an angular unconformity (KC-4). In response to the sudden increase in sediment supply and rapid progradation, the deep-sea area tends to form a large-scale, multistage overlying channel-levee system (Iboum et al., 2016).

\subsubsection{Relative sea-level fluctuations}

The Maastrichtian is synonymous with sea-level rise and the widening of the Atlantic Ocean, driven by continental drift (Le, 2012 and Sterling, 2010). As a result, deposition in the study area changed from the basin-bottom fans during the Campanian (KC-3) to the more incised submarine channel systems during the Maastrichtian (KC-4) (Fig. 5). The KC-4 surface associated with channel system corresponds to the Cretaceous-Tertiary erosional surface or BLCU (Base Late Cretaceous Unconformity) reported by Lawrence et al. (2002) throughout the margin. According to the global eustatic curve of Haq et al. (1987), the channel system in the study area developed during a long-term rise in relative sea level during the Maastrichtian although punctuated by occasional declines in relative sea level.

\subsubsection{Fluvial sediment supply}

It is known that following the Santonian tectonic event, a large amount of terrigenous sediment was transported to deep-water basins, forming a widely developed deep-water gravity channel system in the Maastrichtian (SPT, 1995). During this time, sediment supply from the Sanaga River also played a significant role in controlling the development of the two-stage submarine channel systems. Coarse clastic sediments are therefore predicted to have been extensively deposited in the study area, particularly in the vicinity of the Sanaga River (SPT, 1995). The infilling of the submarine channel system in this study reflects a deltaic (Sanaga and Nyong) origin of the sediments deposited on the continental shelf margin in the northeast of the study area. The NE-SW trending channels mapped in this study indicate that sediments originate primarily to the northeast (Figs. 9 and 12). This corroborates the interpretation made by Meyers et al. (1996), Iboum et al. (2016), and Yugye et al. (2021).

\subsubsection{Paleotopographic gradient}

Paleotopographic gradient features appear to have played a key role in controlling the internal architecture and fills of the submarine channel in the Late Cretaceous. The highest amplitudes observed in the map view characterize areas of lower channel gradient, while the lowest amplitude channel amplitude areas are in the upslope to the mid-slope of the channel and characterize the high gradient (Fig. 9). Thus, the amplitude change may reflect a change in lithology from fine to coarse-grained deposits (Sullivan et al., 2000; Morend et al., 2002). In the case of the slope segments $\mathrm{x}$, the low amplitude lithofacies corresponds to fine-grained 
deposits. On the other hand, when the slope is low (segment z), high amplitude lithofacies indicate deposits of coarse-grained deposits (Figs. 9 and 12). This type of sedimentary submarine channel fill is similar to the indented sedimentary channel fill suggested by Li et al. (2020).

\subsection{Implications for hydrocarbon exploration in deep-water Kribi-Campo sub-basin}

Turbidite channel systems are one of the most common types of hydrocarbon reservoirs found along the West Africa margin and elsewhere (Weimer et al., 2000). Therefore, the discovery of these late Cretaceous submarine channels system, have implications for hydrocarbon prospectivity in the deep-water Kribi-Campo sub-basin.

The early-stage channel consists of coarse grain sediments alternating with fine grain sediments rather than being isolated on a basal erosional surface, suggesting multiple barriers and possible thief zones at the base of the channel (Figs. 8 and 9; Mayall et al., 2006). In addition, the late-stage channel is predominantly fine-grained. However, the presence of coarsegrained sediments in the early-stage channel originating from erosive energetic flows may result into good reservoirs in the study area (Loule et al., 2018; Sterling, 2010; Jobe et al., 2011).

Sediment transport models indicate that grain size distribution, as well as slope gradients, are key variables dictating the presence of good reservoir development (McCaffrey and Kneller, 2001; Stevenson et al., 2015). The coarse-grained sediments of the early-stage channel in this study were deposited along the low slope gradients (segment $\mathrm{z}$ ) and the fine-grained sediments were deposited in the high slope gradients (segment $\mathrm{x}$ ) (Figs. 9d and 12). As a result, the channel system with gentle gradients and coarse-grained sediments offers the highest potential for hydrocarbon discoveries (McCaffrey and Kneller, 2001; Stevenson et al., 2015).

Another potential application of this study lies in the well-log motif of the submarine channel system where various stages of channel evolution have distinct logs responses (Fig. 8). The basal coarse-grained lags of the early-stage channel in well W1 show a large kick in GR and display a serrate GR log motif with some blocky/bell-shaped intervals (Well W1 in Fig. 8). The late-stage channel fills are mainly characterized by a serrate GR motif with some lowamplitude bell-shaped GR intervals (Fig. 8a). The log responses observed in this study is similar to those reported from other slope channel systems (e.g., Fig. 11 of Mayall et al., 2006; Fig. 10 of $\mathrm{Li}$ et al.2021). This suggests that evolutionary stages and associated 2D or 3D reservoir elements of submarine channel systems may be recognized from 1D vertical log patterns or sections.

\section{Conclusions}

Integrated analysis of a high-resolution, 3D seismic reflection dataset and borehole data from the deep-water Kribi-Campo Sub-basin, offshore Cameroon has revealed a submarine channel system that developed during the Late Cretaceous. The channel system is U-shaped, $56 \mathrm{~km}$ long with a maximum width and height of $5 \mathrm{~km}$ and $197 \mathrm{~m}$ respectively within the study area. The submarine channel system consists of two parts: (1) the early-stage channel with a linear morphology and: (2) the late-stage channel located within the early channel which is narrower with a sinuous morphology. The geometry and internal characteristics are primarily controlled by tectonics, relative sea-level change, sediment supply and slope topography. The filling of the channel system occurred during a long-term Maastrichtian relative sea-level rise, punctuated by falls in relative sea level. The filling of the channel may reflect a delta-fed origin for the sediment deposited on the continental shelf margin. The lithology of the sediments throughout the system is dominated by fine-grained sediments although there are lesser indications of coarse-grained areas and has a northeast origin that constitutes the sediment 
supply. Decreasing slope gradient favours coarser-grained deposits primarily along the axis of the channel system, while a strong slope gradient leads to the deposition of fine-grained sediments. This insight into deep-water channel morphology is important for facies prediction and efficient development of deep-water channel reservoirs especially as hydrocarbon exploration transits into deeper waters.

\section{Acknowledgements}

The authors are grateful to the National Hydrocarbon Corporation (NHC), Yaoundé (Cameroon) for providing the seismic and well data used in this study for the permission to publish this work.

\section{References}

Abreu, V., Sullivan, M., Pirmez, C., Mohrig, D., 2003. Lateral accretion packages (LAPs): an important reservoir element in deep water sinuous channels. Mar. Petrol. Geol. 20 (6-8), 631648.

Ackerman, W.C., Boatwright, D.C., Burwood, B.M., Van Lerberche, D., Bondjo, E., Tamfu, S.F., Ovono, D., 1993. Geochemical analysis of selected hydrocarbon samples in the Douala Basin, Cameroon. Implications for an oil-prone source rock. AAPG Bull 77 (9): 1604.

Adeogba, A.A., McHargue, T.R., Graham, S.A., 2005. Transient fan architecture and depositional controls from near-surface 3-D seismic data, Niger Delta continental slope. AAPG Bull $89: 627-643$.

Babonneau, N., Savoye, B., Cremer, M., Bez, M., 2010. Sedimentary architecture in meanders of a submarine channel: detailed study of the present congo turbidite channel (zaiango project). J. Sediment. Res. 80, 852-866.

Beglinger, S.E., Doust, H., Cloetingh, S., 2012. Relating petroleum system and play development to basin evolution: West African South Atlantic basins. Marine and Petroleum Geology 30:1-25. doi:10.1016/j.marpetgeo.2011.08.008.

Binks, R.M., Fairhead, J.D., 1992. A plate tectonic setting for Mesozoic rifts of West and Central Africa. Tectonophysics 213, 141-151.

Brown, A.R., 2004. Interpretation of Three-dimensional Seismic Data. American Association of Petroleum Geologists and the Society of Exploration Geophysicists.

Brownfield, M.E., 2016. Assessment of Undiscovered Oil and Gas Resources of the WestCentral Coastal Province, West Africa, U.S. Geological Survey, Reston, Virginia, 41p.

Brownfield, M.E., Charpentier, R.R., 2006. Geology and total petroleum systems of the WestCentral Coastal Province (7203), West Africa: U.S. Geological Survey Bulletin 2207-B, 52 p.

Catterall, V., Redfern, J., Gawthorpe, R., Hansen, D., Thomas, M., 2010. Architectural style and quantification of a submarine channel-levee system located in a structurally complex area: offshore Nile Delta: Journal of Sedimentary Research, 80: 991-1017.

Catuneanu, O., 2006. Principles of Sequence Stratigraphy. Elsevier, Amsterdam.

CGG Robertson 2015. Petroleum Geological Evaluation: Niger Delta to the Congo Fan. CGG Robertson Multiclient. Report No. AM086. 
Chen, H., Lin, C., Zhang, Z., Zhang, D., Li, M., Wu, G., Zhu, Y., Xu, H., Lu, W., Chen, J., 2021. Evolution and controlling factors of the gravity flow deposits in the Miocene sequence stratigraphic framework, the Lower Congo-Congo Fan Basin, West Africa. Petroleum Exploration and Development, 48(1): 146-158.

Chiang, C.S., Hsiung, K.H., Yu H.S., Chen, S.C., 2020. Three types of modern submarine canyons on the tectonically active continental margin ofshore southwestern Taiwan. Marine Geophysical Research 41:4.

Chima, K.I., Gorini, C., Rabineau, M., Granjeon, D., Do Couto, D., Leroux, E., Hoggmascall, N., 2020. Pliocene and Pleistocene stratigraphic evolution of the western Niger Delta intraslope basins: a record of glacio-eustatic sea-level and basin tectonic forcings. Global Planet. Change 195 (103355), 1-23. https://doi.org/ 10.1016/j.gloplacha.2020.103355.

Chima, K.I., Do Couto, D., Leroux, E., Gardin, S., Hoggmasacall, N., Rabineau, M., Granjean, D., and Gorini, C., 2019. Seismic stratigraphy and depositional architecture of Neogene intraslope basins, offshore western Niger Delta. Marine and Petroleum Geology 109, 449-468. doi: 10.1016/j.marpetgeo.2019.06.030.

Covault, J.A., Kostic, S., Paull, C.K., Ryan, H.F., Fildani, A., 2014. Submarine channel initiation, filling and maintenance from seafloor geomorphology and morphodynamic modelling of cyclic steps. Sedimentology 61, 1031-1054.

Covault, J.A., Sylvester, Z., Hudec, M.R., Ceyhan, C., Dunlap, D., 2019. Submarine channels 'swept' downstream after bend cutoff in salt basins. The Depositional Record 6, 259-272.

Dailly, P., 2000. Tectonics and stratigraphic development of Rio Muni basin. Equatorial Guinea: the role of transform zone in Atlantic basin evolution. Atlantic Rifts and Continental Margins. Geophysical Monograph Series 115:105-128.

Dailly, P., Lowry P., Goh., and Gene. M., 2002. Exploration and development of Ceiba field, Rio Muni basin, Southern Equatorial Guinea, The leading edge, November, 1140-1146.

Deptuck, M.E., Steffens, G.S., Barton, M., Pirmez, C., 2003. Architecture and evolution of upper fan channel-belts on the Niger Delta slope and in the Arabian Sea. Mar. Pet. Geol. 20, 649-676.

Deptuck, M.E., Sylvester, Z., Pirmez, C., O'Byrne, C., 2007. Migration-aggradation history and 3-D seismic geomorphology of submarine channels in the Pleistocene Benin major Canyon, western Niger Delta slope. Mar. Pet. Geol. 24, 406-433.

Deptuck, M.E., Sylvester, Z., O’Byrne, C., 2012. Pleistocene seascape evolution above a "simple" stepped slope-Western Niger Delta. In: Prather, B.E., Deptuck, M.E., Mohrig, D., Van Hoorn, B., Wynn, R.B. (Eds.), Application of the Principles of Seismic Geomorphology to Continental-slope and Base-of-slope Systems: Case Studies from Seafloor and Near-seafloor Analogues, vol. 99. SEPM Society for Sedimentary Geology, pp. 199-222. https://doi.org/10.2110/pec.12.99.

Di Celma, C., Cantalamessa, G., Didaskalou, P., Lori, P., 2010. Sedimentology, architecture, and sequence stratigraphy of coarse-grained, submarine canyon fills from the 
Pleistocene (Gelasian-Calabrian) of the Peri-Adriatic basin, central Italy. Mar. Pet. Geol. 27, 1340-1365.

Estrada, F., Ercilla, G., Alonso, B., 2005. Quantitative study of a Magdalena submarine channel (Caribbean Sea): implications for sedimentary dynamics. Marine and Petroleum Geology, 22(5): 623-635.

Friedmann, S.J., Beaubouef, R.T., Pirmez, C., Jennette, D.C., 2000. The effects of gradient changes on deep-water depositional systems: an integrated approach: American Association of Petroleum Geologists, 2000 Annual Meeting, Extended Abstracts, New Orleans, U.S., pp. 51.

Fusion Oil \& Gas NL., 2002. Cameroon, Ntem Exploration Permit, Technical Evaluation Report. Proprietary Report, Fusion Oil \& Gas NL.

Gamboa, D., Alves, T.M., 2015. Spatial and dimensional relationships of submarine slope architectural elements: a seismic-scale analysis from the Espírito Santo Basin (SE Brazil). Mar. Pet. Geol. 64, 43-57.

Gamboa, D., Alves, T.M., Cartwright, J., 2012. A submarine channel confluence classification for topographically confined slopes. Mar. Pet. Geol. 35, 176-189. Gee, M.J.R., Uy, H.S., Warren, J., Morley, C.K., Lambiase, J.J., 2007. The Brunei slide: a giant submarine landslide on the North West Borneo Margin revealed by 3D seismic data. Mar. Geol. 246, 9-23.

Gong, C.L., Steel, R.J., Wang, Y.M., et al., 2016. Shelf-margin architecture variability and its role in sediment-budget partitioning into deep-water areas. Earth Sci. Rev. 154, 2-101.

Haq, B.U., Hardenbol, J., Vail, P.R., 1987. Chronology of fluctuating sea levels since the triassic. Science 235, 1156-1167.

Hansen, L., Janocko, M., Kane, I., Kneller, B., 2017. Submarine channel evolution, terrace development, and preservation of intra-channel thin-bedded turbidites: Mahin and Avon channels, offshore Nigeria. Mar. Geol. 383, 146-167.

Harishidayat, D., Omosanya, K.O., Johansen, S.E., Eruteya, O.E., Niyazi, Y., 2018. Morphometric analysis of sediment conduits on a bathymetric high: implications for palaeoenvironment and hydrocarbon prospectivity. Basin Res 30:1015-1041. https://doi.org/10.1111/bre.12291

Helm, C., 2009. Quantification des flux sédimentaires anciens à l'échelle d'un continent: le cas de l'Afrique au Méso-cénozoïque, vol. 1. Thesis. Univ. Rennes, p. 299.

Huang, Y., 2018. Sedimentary characteristics of turbidite fan and its implication for hydrocarbon exploration in Lower Congo Basin. Petroleum Research 3: 189-196

Iboum Kissaaka, J.B., Ntamak-Nida, M.J., Mvondo, F., Fowe Kwetche P.G., Djomeni Nitcheu, A,L,, Abolo, G.M.; 2016. Postrift depositional evolution and sequence stratigraphy from offshore subsurface data of the Kribi-Campo sub basin (Cameroon, West African margin), Society of Exploration Geophysicists and American Association Petroleum Geologists 13: 79101 https://doi.org/10.1190/INT-2015-0073.1.

Janocko, M., Nemec, W., Henriksen, S., Warchoł, M., 2013. The diversity of deep-water sinuous channel belts and slope valley-fill complexes. Mar. Pet. Geol. 41, 7-34. 
Jobe, Z.R., Lowe, D.R. \& Uchytil, S.J., 2011. Two fundamentally different types of submarine canyons along the continental margin of Equatorial Guinea. Marine and Petroleum Geology, 28(3): 843-860.

Jobe, Z.R., Sylvester, Z., Parker, A.O., Howes, N., Slowey, N., and Pirmez, C., 2015. Rapid adjustment of submarine channel architecture to changes in sediment supply: Journal of Sedimentary Research, 85: 729-753, doi:10.2110/jsr.2015.30.

Jolly, B.A., Lonergan, L., Whittaker, A.C., 2015. Growth history of fault-related folds and interaction with seabed channels in the toe-thrust region of the deep-water Niger Delta. Marine and Petroleum Geology 70, 58-76.

Kane, I.A., Mc Caff rey, W.D., Peakall, J., 2008. Controls on sinuosity evolution within submarine channels. Geology 36 (4), 287-290.

Kneller, B., 2003. The influence of flow parameters on turbidite slope channel architecture. Marine and Petroleum Geology 20, 901-910.

Kolla, V., Posamentier, H.W., Wood, L.J., 2007. Deep-water and fluvial sinuous channels characteristics, similarities and dissimilarities, and modes of formation. Mar. Pet. Geol. 24, 388-405.

Labourdette, R., Bez, M., 2010. Element migration in turbidite systems: random or systematic depositional processes? AAPG (Am. Assoc. Pet. Geol.) Bull. 94 (3), 345-368.

Lawrence, R.S., Beach, A., Owain, J., Jackson, A., 2016. Deformation of oceanic crust in the eastern Gulf of Guinea: role in the evolution of the Cameroon Volcanic Line and influence on the petroleum endowment of the Douala-Rio Muni Basin, Geological Society of London, 438.

Lawrence, R.S., Munday, S., Bray, R., 2002. Regional geology and geophysics of the eastern gulf of Guinea (Niger Delta). The leading Edge, pp 1112-1117.

Le, A.N., 2021. Striations at the Base of the Paleo-Fan and Channel revealed by 3D Seismic Data, Offshore Cameroon, Indonesian Journal on Geoscience 8: 101-107.

Le, A.N., 2012. Stratigraphic Evolution and Plumbing System in the Cameroon Margin, West Africa. Thesis for the Degree of Doctor of Philosophy, Faculty of Engineering and Physical Science, University of Manchester

Le, A.N., Huuse, M., Redfern, J., Gawthorpe, R.L., Irving, D., 2014. Seismic characterization of a Bottom Simulating Reflection (BSR) and plumbing system of the Cameroon margin, offshore West Africa, Marine and Petroleum Geology 68: 629-647.

Li, Q., Wu, W., Liang, J., Kang, H., Liu, W., Wang, G., Cai, L., 2020. Deep-water channels in the lower Congo basin: Evolution of the geomorphology and depositional environment during the Miocene, Marine and Petroleum Geology 115: 104260 doi.org/10.1016/j.marpetgeo.2020.104260.

Li, S., Gong, C., 2016. Flow dynamics and sedimentation of lateral accretion packages in sinuous deep-water channels: a 3D seismic case study from the northwestern South China Sea margin. J. Asian Earth Sci. 124, 233-246. 
Lin, H.M., Shi, H.S., 2014. Hydrocarbon accumulation conditions and exploration direction of Baiyun-Liwan deep water areas in the Pearl River Mouth Basin. Nat. Gas. Ind. B1, 150-158.

Loule, J.P., Jifon, F., Angoua Biouele, S.E., Nguema, P., Spofforth, D., Carruthers, D., Watkins, C., Johnston, J., 2018. An opportunity to re-evaluate the petroleum potential of the Douala/Kribi-Campo Basin, Cameroon. Special topic: Petroleum Geology. First break 36: 6170.

Marsden, D., 1989. Layer cake depth conversion. Geophys Lead Edge 8: 10-14.

Marsset, T., Droz, L., Dennielou, B., Pichon, E., 2009. Cycles in the architecture of the Quaternary Zaïre turbidite system: a possible link with climate. In: Kneller, B., Martinsen, O.J., McCaff rey, B. (Eds.), Extern. Controls Deep-Water Depositional Systems, vol. 92. SEPM, Special Publication, pp. 89-106.

Mayall, M., Jones, E., Casey, M., 2006. Turbidite reservoirs-key elements in facies prediction and effective development. Marine and Petroleum Geology 23, 821-841.

McCaffrey, W. \& Kneller, B. 2001. Process controls on the development of stratigraphic trap potential on the margins of confined turbidite systems and aids to reservoir evaluation. AAPG bulletin, 85(6): 971-988.

McHargue, T., Pyrcz, M.J., Sullivan, M.D., Clark, J.D., Fildani, A., Romans, B.W., Covault, J.A., Levy, M., Posamentier, H.W., Drinkwater, N.J., 2011. Architecture of turbidite channel systems on the continental slope: patterns and predictions. Mar. Petrol. Geol. 28 (3), 728-743.

Meyers, J.B., Rosendhal, B.R., Groschel-Becker, H., Austin, J.J.A., Rona, P.A., 1996. Deep penetrating MCS imaging of the rift-to-drift transition, offshore Douala and North Gabon Basins, West Africa. Marine and Petroleum Geology 13, pp 791-835. https://doi:10.1016/0264$8172(96) 00030-X$.

Miall, A.D., 1989. Architectural elements and bounding surfaces in channelized clastic deposits: Notes on comparisons between fluvial and turbidite systems. Sedimentary facies in the active plate margin: Tokyo, Terra Scientific Publishing Company: 3-15.

Mienlam Essi, M.F., Yene Atangana, J.Q., Abate Essi, J.M., Mbida Yem., Angoua Biouele, S.E., Nguema, P., Tsimi Ntsengue, C., 2021. Stratigraphical nature of the Top Albian surface, from seismic and wells data analyses, in the south Sanaga area (Cameroon Atlantic margin): Palaeogeographical significance and petroleum implications. Marine and Petroleum Geology 129: 105073. doi.org/10.1016/j.marpetgeo.2021.105073

Mitchell, W.H., Whittaker, A.C., Mayall, M., Lonergan, L., 2021. New models for submarine channel deposits on structurally complex slopes: Examples from the Niger delta system. Marine and Petroleum Geology 129: 105040. doi.org/10.1016/j.marpetgeo.2021.105040

Mitchum, Jr., Vail, P.R., Sangree, J.B., 1977. Seismic stratigraphy and global changes of sea level: part 6. In: Stratigraphic Interpretation of Seismic Reflection Patterns in Depositional Sequences: Section 2. Application of Seismic Reflection Configuration to Stratigraphic Interpretation.

Morend, D., Pugin, A., and Gorin, G.E., 2002. High-resolution seismic imaging of outcrop-scale channels and an incised-valley system within the fluvial-dominated 
Lower Freshwater Molasse (Aquitanian, western Swiss Molasse Basin): Sedimentary 764 Geology 149: 245-264.

Mutti, E., Normark, W.R., 1987. Comparing examples of modern and ancient turbidite systems: problems and concepts. In: Legett, J.K., Zuffa, G.G. (Eds.), Marine Clastic Sedimentology: Concepts and Case Studies. Graham and Trotman, London, pp. $1-38$.

Mvondo, O.F., 2010. Surrection cénozoïque l'Ouest de l'Afrique à partir de deux exemples : le plateau sud-namibien et la marge nord camerounaise. Thèse de Doctorat, Université de Rennes, p. 324.

Ndonwie Mahbou, E., 2007. Petrophysical characterization of petroleum reservoirs and source beds of the Batanga sub-block, Kribi-Campo sub-basin, Cameroon. AAPG Annual Convention, Abstract, $1 \mathrm{p}$

Ngo, E.N.J., Ntamak-Nida, M.J., Bisso, D., Mvondo Owono, F., Ngos III, S., Bilong, P., Njandjock Nouck, P., 2018. Depocenters Repartition and Sequence Stratigraphy of the Northern Part of the Kribi-Campo sub-basin (Cameroon). European Journal of Scientific Research 149: 258-278.

Nguene, F.R., Tamfu, S., Loule, J., Ngassa, C., 1992. Palaeoenvironments of the Douala and Kribi/Campo sub-basins, in Cameroon, west Africa, in Curnelle,R.,ed., Géologie Africaine, 1er Colloque de Stratigraphie et de Paléogéographie des Bassins Sédimentaires Ouest-Africains, 2e Colloque Africain de Micropaléontologie, Libreville, Gabon, 1991, Recueil des Communications: Boussens, Elf Aquitaine, pp 129-139.

Ngueutchoua, G., Giresse, P., 2010. Sand bodies and incised valleys within the Late Quaternary Sanaga-Nyong delta complex on the middle continental shelf of Cameroon: Marine and Petroleum Geology (27)10:2173-2188. doi:10.1016/j.marpetgeo.2010.06.011.

Niyazi, Y., Eruteya, O.E., Omosanya, K.O., Harishidayat, D., Johansen, S.E., Waldmann, N., 2018. Seismic geomorphology of submarine channel-belt complexes in the Pliocene of the Levant basin. Offshore Central Israel. Mar. Geol. 403, 123-128.

Normark, W.R., Piper, D.J.W., 1991. Initiation processes and flow evolution of turbidity currents: Implications for the depositional record. SEPM Special Publication 46, 207-230. https://doi.org/10.2110/pec.91.09.0207.

Normark, W.R., \& Carlson, P.R., 2003. Giant submarine canyons: Is size any clue to their importance in the rock record? Geological Society of America Special Papers, 370: $175-190$.

Ntamak-Nida, M.J, Bourquin, S., Makong, J.C., Baudin, F., Mpesse, J.E., Ngouem, C.I., Komguem, P.B., Abolo, G.M., 2010. Sedimentology and sequence stratigraphy from outcrops of the Kribi-Campo sub-basin: lower Mundeck Formation (Lower Cretaceous, Southern Cameroon). J Afr Earth Sci 58:1-18. https://doi.org/10.1016/j.jafrearsci.2010.01.004.

Omosanya, K.O., Alves, T.M., 2013. A 3-dimensional seismic method to assess the provenance of Mass-Transport Deposits (MTDs) on salt-rich continental slopes (Espírito Santo Basin, SE Brazil). Mar. Pet. Geol. 44, 223-239. http://dx.doi.org/10.1016/j. marpetgeo.2013.02.006. 
Pauken, R.J., 1992. Sanaga Sud field, offshore Cameroon, West Africa, in M. T. Halbouty, ed., Giant oil and gas fields of the decade 1978-1988: AAPG Bull 54: 217-230.

Pauken, R.J., Thompson JM, Schuman JR, Cooke JC (1991) Geology of the Douala Basin, offshore Cameroon. AAPG Bull 75 (3): 651-652

Peakall, J., Sumner, E.J., 2015. Submarine channel flow processes and deposits: a process$\begin{array}{llll}\text { product } & \text { Gerspective. } & \text { G5-120. }\end{array}$ https://doi.org/10.1016/j.geomorph.2015.03.005.

Picot, M., Droz, L., Marsset, T., Dennielou, B., Bez, M., 2016. Controls on turbidite sedimentation: insights from a quantitative approach of submarine channel and lobe architecture (Late Quaternary Congo Fan). Mar. Petrol. Geol. 72, 423-446.

Posamentier, H. \& Walker, R.G., 2006. Deep-water turbidites and submarine fans. Facies models revisited, vol.84, SEPM Special Publication: 397-520.

Posamentier, H.W. Kolla, V., 2003. Seismic geomorphology and stratigraphy of depositional elements in deep-water settings. J. Sediment. Res 73: 367-388. https://doi.org/10.1306/111302730367

Qin, Y., Alves, T.M., Constantine, J. \& Gamboa, D. 2016. Quantitative seismic geomorphology of a submarine channel system in SE Brazil (Espírito Santo Basin): Scale comparison with other submarine channel systems. Marine and Petroleum Geology, 78: 455-473.

Rabinowitz, P., and LaBrecque J., 1979. The Mesozoic South Atlantic Ocean and evolution of its continental margins, J. Geophys. Res., 84(B11):5973-6002

Reading, H.G., Richards, M., 1994. Turbidite systems in deep-water basin margins classifed by grain size and feeder system. American Association of Petroleum Geologists Bulletin 78:792-822.

Rosendahl, B.R., Groschel-Becker, H., 1999. Deep seismic structure of the continental margin in the Gulf of Guinea: a summary report. In: Cameron, N.R., Bate, R.H. and Clure, V.S. (eds). The oil and Gas habitats of the South Atlantic. Geological Society, London, Special Publications, 153, 75-83.

Seranne, M., Seguret, M., Fauchier, M., 1992. Seismic super-units and post-rift evolution of the continental passive margin of sourthern Gabon. Bulletin Societe Geologique de France, 163: 135-146.

Shanmugam, G., 2006. Deep-water processes and facies models: Implications for sandstone petroleum reservoirs, 5. Elsevier

Shepard, F.P., 1981. Submarine canyons: multiple causes and long-time persistence. AAPG Bulletin, 65(6): 1062-1077.

Shumaker, L., Jobe, Z., Johnstone, S., Pettinga, L., Cai, D., Moody, J., 2018. Controls on submarine channel-modifying processes identifed through morphometric scaling relationships. Geosphere 14 (5), 2171-2187

SPT/Simon Petroleum and Technology., 1995. Petroleum Geology and Hydrocarbon Potential of Douala Basin, Cameroon. Unpubl. Non-exclusive report. 
Sterling Cameroon Limited., 2010. Prospectivity review of the Ntem Block (PH-78) in the Douala/Kribi-Campo basin. Unpublished report.

Stevenson, C.J., Jackson, C.A.-L., Hodgson, D.M., Hubbard, S.M. \& Eggenhuisen, J.T., 2015. Deep-water sediment bypass. Journal of Sedimentary Research, 85(9): 1058-1081.

Stow, D.A.V. \& Mayall, M., 2000. Deep-water sedimentary systems: New models for the 21st century. Marine and Petroleum Geology, 17(2): 125-135.

Su, M., Hsiung, K.H., Zhang, C.M., Xie, X.N., Yu, H.S., Wang, Z.F., 2015. The linkage between longitudinal sediment routing systems and basin types in the northern South China Sea in perspective of source-to-sink. J. Asian Earth Sci. 111, 1-13.

Sullivan, M.D., Jensen, G.N., Goulding, F.J., Jennette, D.C., Foreman, J.L., Stern, D., 2000. Architectural analysis of deep-water outcrops: Implications for exploration and production of the Diana Sub-basin, western Gulf of Mexico. In: Weimer, P., Slatt, R.M., Coleman, J., Rosen, N.C., Nelson, H., Bouma, A.H., Styzen, M.J., Lawrence, D.T. (Eds.), Deep-Water Reservoirs of The World. Gulf Coast Section SEPM 20th Bob F. Perkins Research Conference, pp. 1010-1032

Sylvester, Z., Covault, J.A., 2016. Development of cutoff-related knickpoints during early evolution of submarine channels. Geology 44, 835-838.

Sylvester, Z., Pirmez, C., Cantelli, A., 2011. A model of submarine channel-levee evolution based on channel trajectories: implications for stratigraphic architecture. Mar. Pet. Geol. 28, $716-727$.

Tamfu, S.F., Batupe, M., Pauken, R.J., Boatwright, D.C., 1995. Geological setting, stratigraphy and hydrocarbon habitat of the Douala Basin, Cameroon. AAPG Bull 79 (13): 95

Taner, M.T., 2001. Seismic attributes. In: CSEG Recorder. 26: 48-56.

Tek, D.E., Mcarthur, A.D., Poyatos-Moré, M., Colombera, L., Patacci, M., craven, B., Mccaffrey, W.D., 2021. Relating seafloor geomorphology to subsurface architecture: How masstransport deposits and knickpoint-zones build the stratigraphy of the deep-water Hikurangi Channel. Sedimentology; doi:10.1111/SED.12890

Turner, J.P., 1999. Detachment faulting and petroleum prospectivity in the Rio Muni Basin, Equatorial Guinea, West Africa. In: Cameron, N. R., Bate, R. H. \& Clure, V. S. (eds) The Oil and Gas Habitats of the South Atlantic. Geological Society, London, Special Publication 153: 303-320

Turner, J.P., 1995. Gravity-driven structures and rift basin evolution: Rio Muni Basin, offshore West Africa. Am. Assoc. Petr. Geol. Bull. 79 (8):1138-1158.

Twichell, D., Nelson, C.H., Kenyon, N. \& Schwab, W., 2009. The influence of external processes on the Holocene evolution of the Mississippi Fan. External controls on deepwater depositional systems. Society for Sedimentary Geology Special Publication, 92:145-157.

Weaver, P.P.E., Wynn, R.B., Kenyon, N.H., Evans, J., 2000. Continental margin sedimentation, with special reference to the north-east Atlantic margin. Sedimentology 47, 239-256.

Weimer, P., Slatt, R.M., Bouroullec, R., 2007. Introduction to the petroleum geology of Deep-water settings. AAPG/Datapages Tulsa. 
Weimer, P., Slatt, R.M., Coleman, J., Rosen, N.C., Nelson, H., Bouma, A.H., Styzen, M.J., Lawrence, D.T. (Eds.), 2000. Deep-water Reservoirs of the World. Gulf Coast Section SEPM 20th Bob F. Perkins Research Conference.

Wonham, J.P., Jayr, S., Mougamba, R., Chuilon, P., 2000. 3D sedimentary evolution of a canyon fill (Lower Miocene-age) from the Mandorove Formation, offshore Gabon. Marine and Petroleum Geology 17: 175-197.

Wornardt, W.W.Jr., Jory, P., Batupe, M., 1999. Seismic Sequence Stratigraphic analysis of The Douala Basin, Cameroon. Offshore Technology Conference. Houston, Texas-1999.

Wu, W., Li, Q., Yu, J., et al., 2018. The Central Canyon depositional patterns and filling process in east of Lingshui Depression, Qiongdongnan Basin, northern South China Sea. Geol. J. 53, 3064-3081.

Wynn, R.B., Cronin, B.T., Peakall, J., 2007. Sinuous deep-water channels: genesis, geometry and architecture. Mar. Petrol. Geol. 24 (6-9), 341-387. doi.org/10.1016/j.marpetgeo.2007.06.001.

Yugye, J.A., Ngos III, S., Angoua Biouele, S.E., Nkoa Nkoa, P.E., 2021. Seismic stratigraphic interpretation and modeling of offshore synrift and postrift Cretaceous sequences in the Kribi-Campo sub-basin, southern Cameroon. AAPG Bulletin, 105(11):1-20. doi: 10.1306/06092118040.

Zeng, H.L., Ambrose, W.A., 2001. Seismic sedimentology and regional depositional systems in Miocene Norte, lake Maracibo, Venezuela. Lead. Edge 20 (11), 1260-1269.

Zeng, H.L., Backus, M.M., Barrow, K.T., Tyler, N., 1998a. Stratal slicing, part I: realistic 3-D seismic model. Geophysics 63 (2), 502-513.

Zhao, X.M., Qi, K., Liu, L., Xie, T., Li, M.H., Hu, G.Y., 2018. Quantitative characterization and controlling factor analysis of the morphology of bukuma-minor channel on southern Niger Delta slope. Interpretation 6, 57-69. doi.org/10.1190/INT-2017-0147.1.

\section{Figure captions}

Figure 1: Superimposed relief and bathymetric map of Cameroon, showing the location of the study area. Insert map on the left-hand corner of the map shows the location of Cameroon in the Gulf of Guinea. The 3D block, which we studied is outlined in red box, while the red cirles with black outlines labelled P1 and P2, represent well locations (Modified from Le et al., 2014; Loule et al., 2018; Le, 2021).

Figure 2: Stratigraphic column of the Kribi-Campo sub-basin showing the tectono-sedimentary phases and global mean sea level (Modified from Pauken, 1992; Lawrence et al., 2002; CGG Robertson, 2015; Iboum Kissaaka et al., 2016).

Figure 3: a) A seismic cross section showing the definition of width and depth as used in this paper. The distances between two intersection points on the top surface and the left/right boundary are defined as the width, the vertical distance between the thalweg and the top surface 
as the depth. b) Schematic diagram showing the definition of the along channel length and channel thalweg.

Figure 4: a) Regional seismic line through $\mathrm{W} 1$ well showing the entire basin successions and channel complex deposits identified within the dataset. Ten Horizon name (KC-1 to KC-9 and the seafloor) are identified in the study area based on Le (2012); Iboum et al. (2016) and Loule et al. (2018). b) Seismic section, taken perpendicular to regional dip, showing the channel complex deposits in study interval. The location of the seismic section is shown in Fig. 1. c) Depth conversion scheme.

Figure 5: Seimic stratigraphy of the slope. The submarine channel system is located within unit (SU2) and deep-water fan is located within (SU1) in the study interval.

Figure 6: a) Isochronal map of the KC 03 horizon. b) Isochronal map of the KC 04 horizon. c) Isopach map of Late Cretaceous between KC 03 and KC 04.

Figure 7: a) Seismic profile showing the channel geometry is U-shaped and iso-proportional slice used to unravel the internal architecture of the channel. b) and c) Channel system is composed of two stages: early-stage channel and late-stage channel. SF1 is coarse while SF2 is fine sediments. The submarine channel is $56 \mathrm{~km}$ long and $3-5 \mathrm{~km}$ wide with an incision depth of $89-197 \mathrm{~m}$.

Figure 8: Characteristic of study unit from the well-seismic calibration, a) Wireline logs (gamma ray (GR), neutron, density, and resistivity) for well W1 through the submarine channel system. b) submarine channel time slices showing two incision stages and flattened horizon KC-04.

Figure 9: Variance and RMS seismic attributes and their interpretations, of the various slices within the early-stage channel and late-stage channel (see Figure 7a). The seismic attributes analysis shows the distribution of several types of sediments deposited during the evolution of the submarine channel system. The late-stage channel is narrower and is more sinuous

Figure 10: Series of line drawings of seismic profiles oriented perpendicular to the orientation of the submarine channel system (every other profile shown, from $1 \mathrm{~km}$ spaced profiles). Notice the variation in the geometry and infill of the channel system along the slope

Figure 11: Quantitative analysis of the submarine channel system. a) Width of early-stage channel and late-stage channel. b) Early-stage channel and late-stage channel depth profile. c) Aspect ratio (width/depth) of the early-stage channel and late-stage channel. d) Depth profile of channel thalweg along the channel.

Figure 12: Diagram of the deposition facies in the study area showing the temporal and spatial evolution of the Late Cretaceous submarine channel. a) Turbidites fan came into being first before the formation of the early-stage of the channel which characterized by Sand-prone sediments and some Clay-prone sediments. b) Then, late-stage channel deposit is narrow and is more sinuous characterized by Clay-prone.

\section{Table captions}

Table 1: Description and the interpretation of the seismic facies observed in the submarine channel system in study interval.

Table 2: The result of morphological analysis along the submarine channel system. 


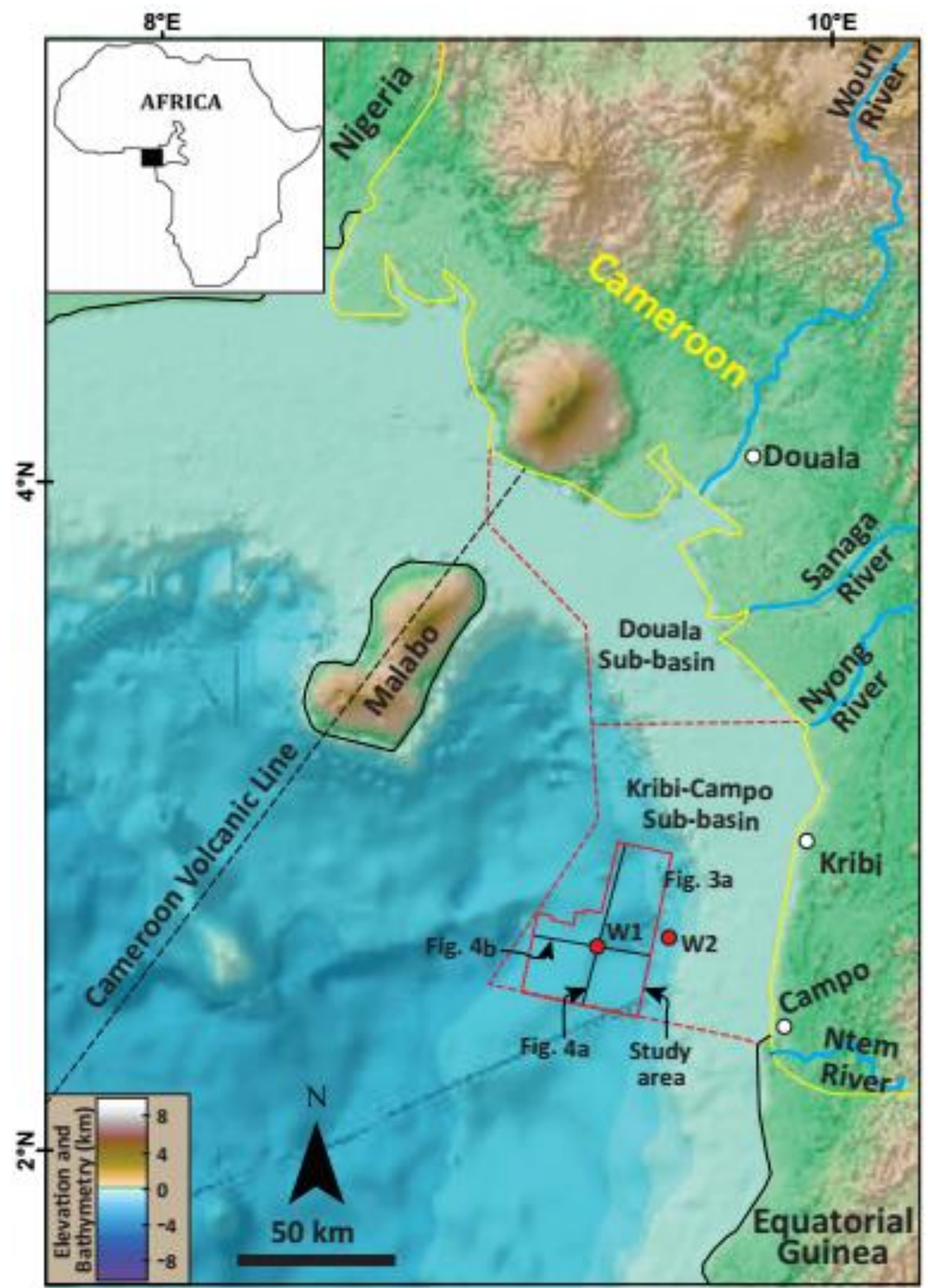

974 Figure 1 


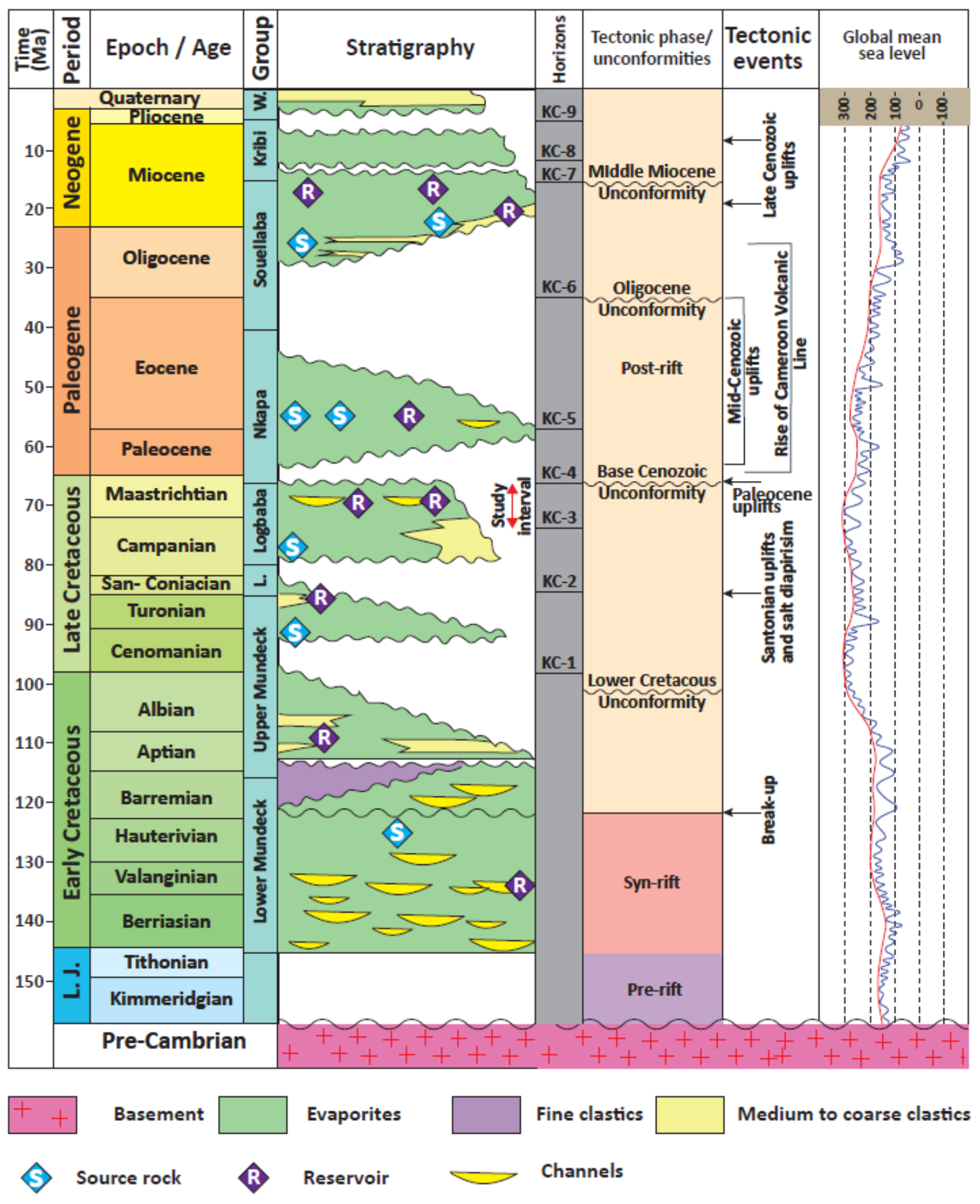

Figure 2 

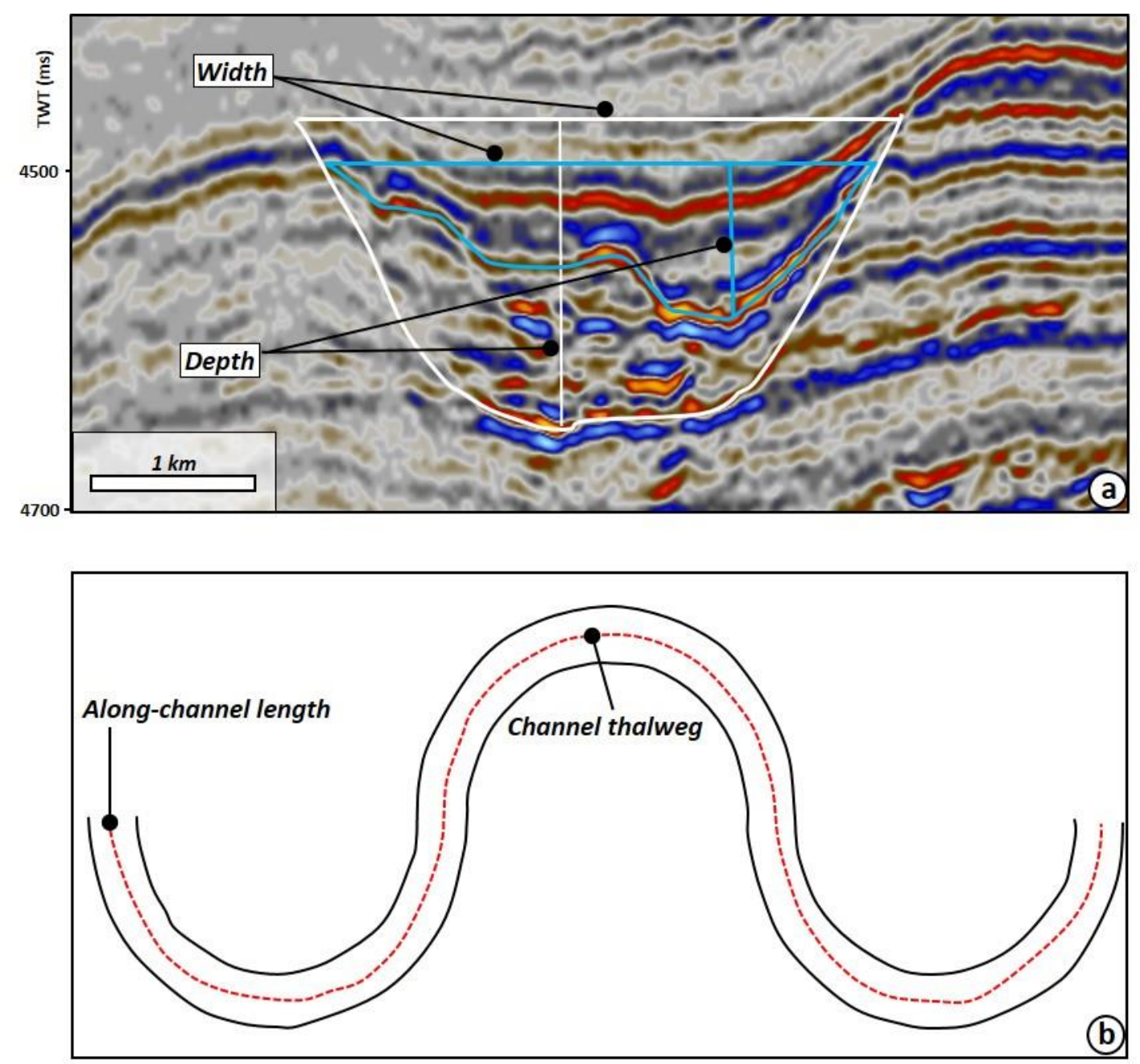

$984 \quad$ Figure 3

985

986

987

988

989

990

991

992

993

994

995

996

997 

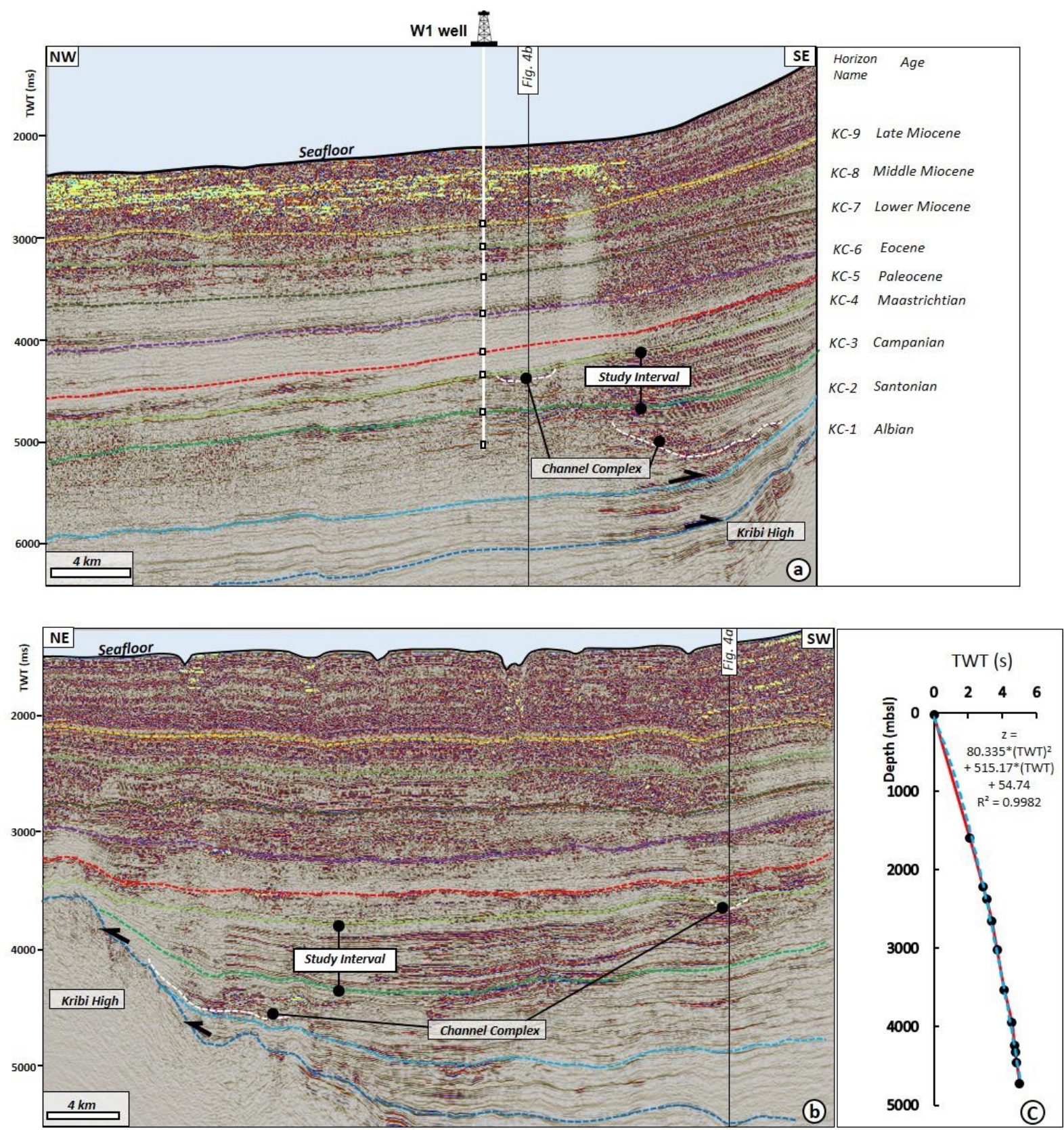

$999 \quad$ Figure 4

1000

1001

1002

1003

1004

1005

1006

1007 


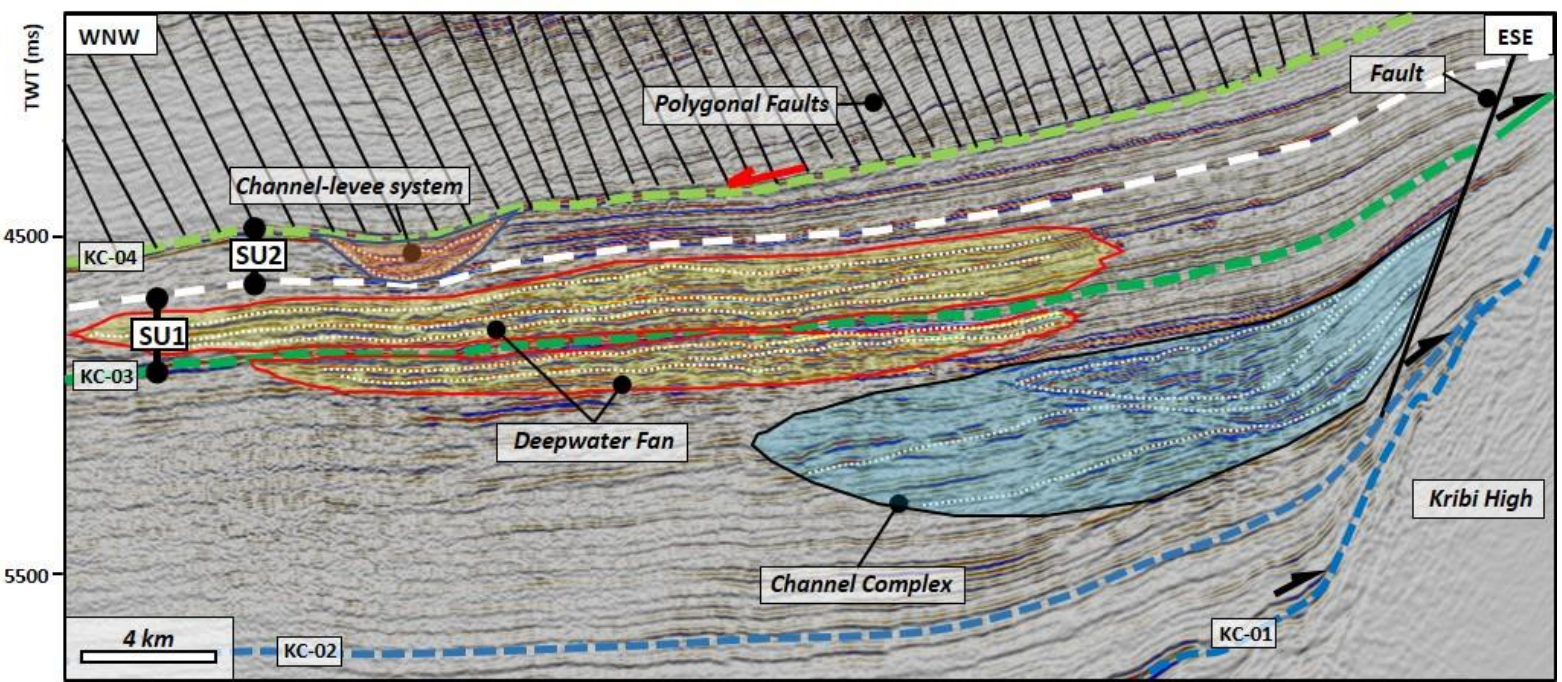

1009 Figure 5

1010

1011

1012

1013

1014

1015

1016

1017

1018

1019

1020

1021

1022

1023

1024

1025

1026

1027

1028

1029 


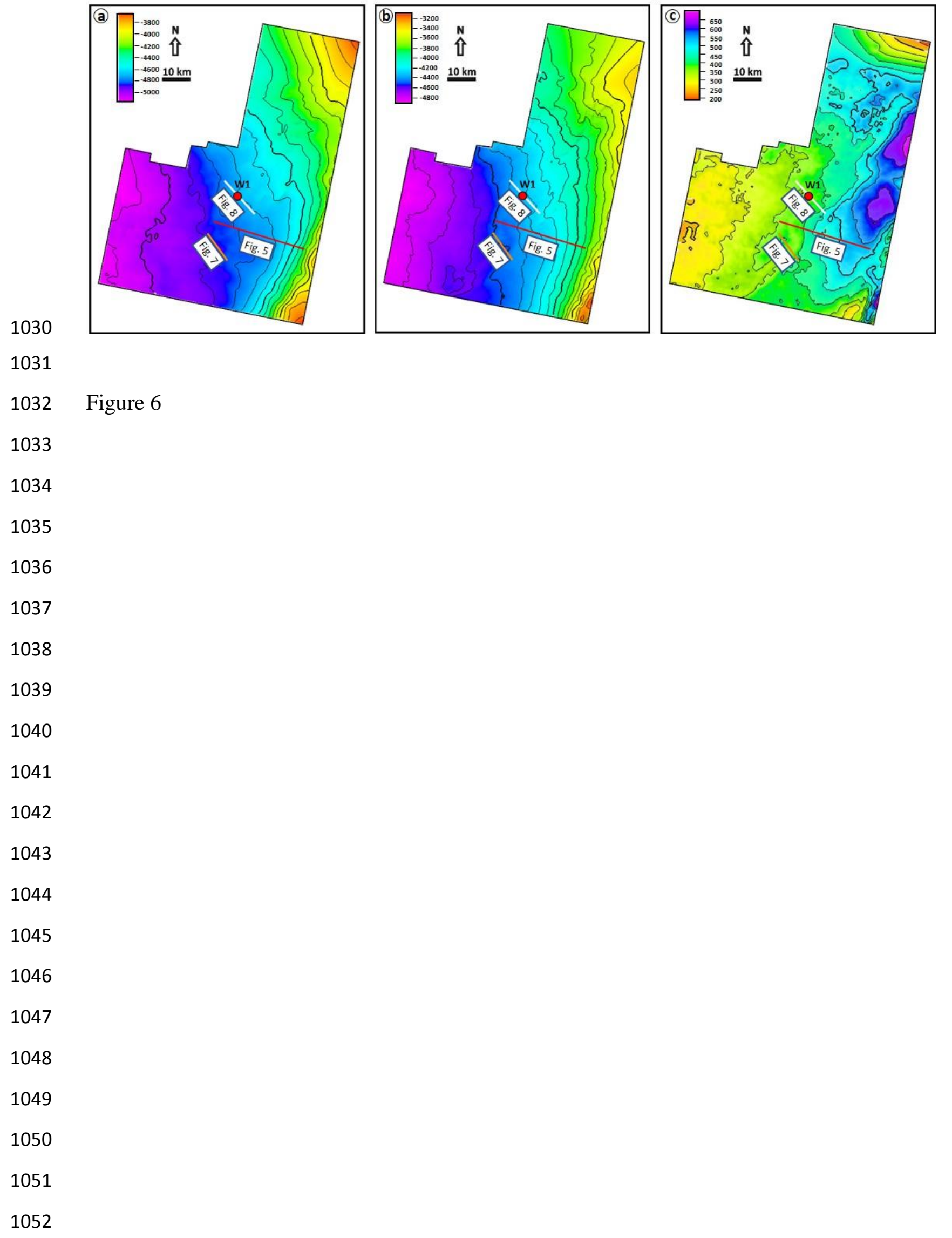






1053

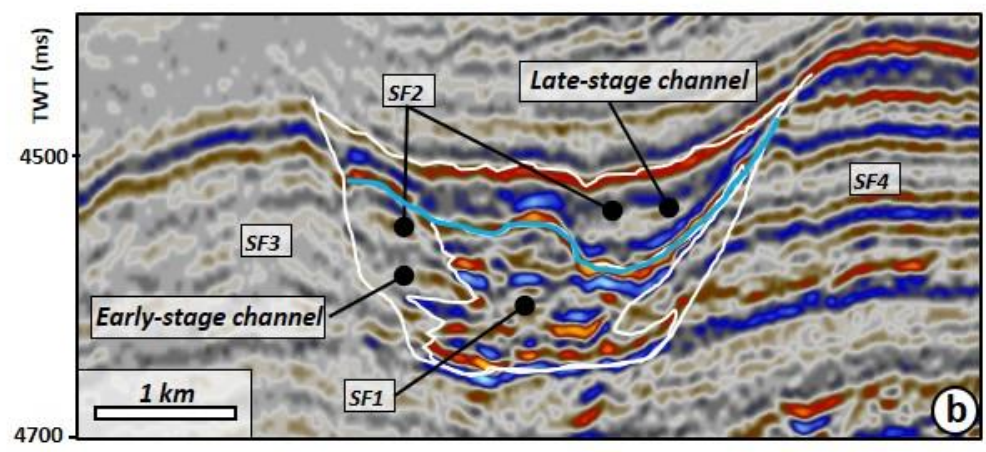

1054

Figure 7

1055

1056

1057

1058

1059

1060

1061

1062

1063

1064






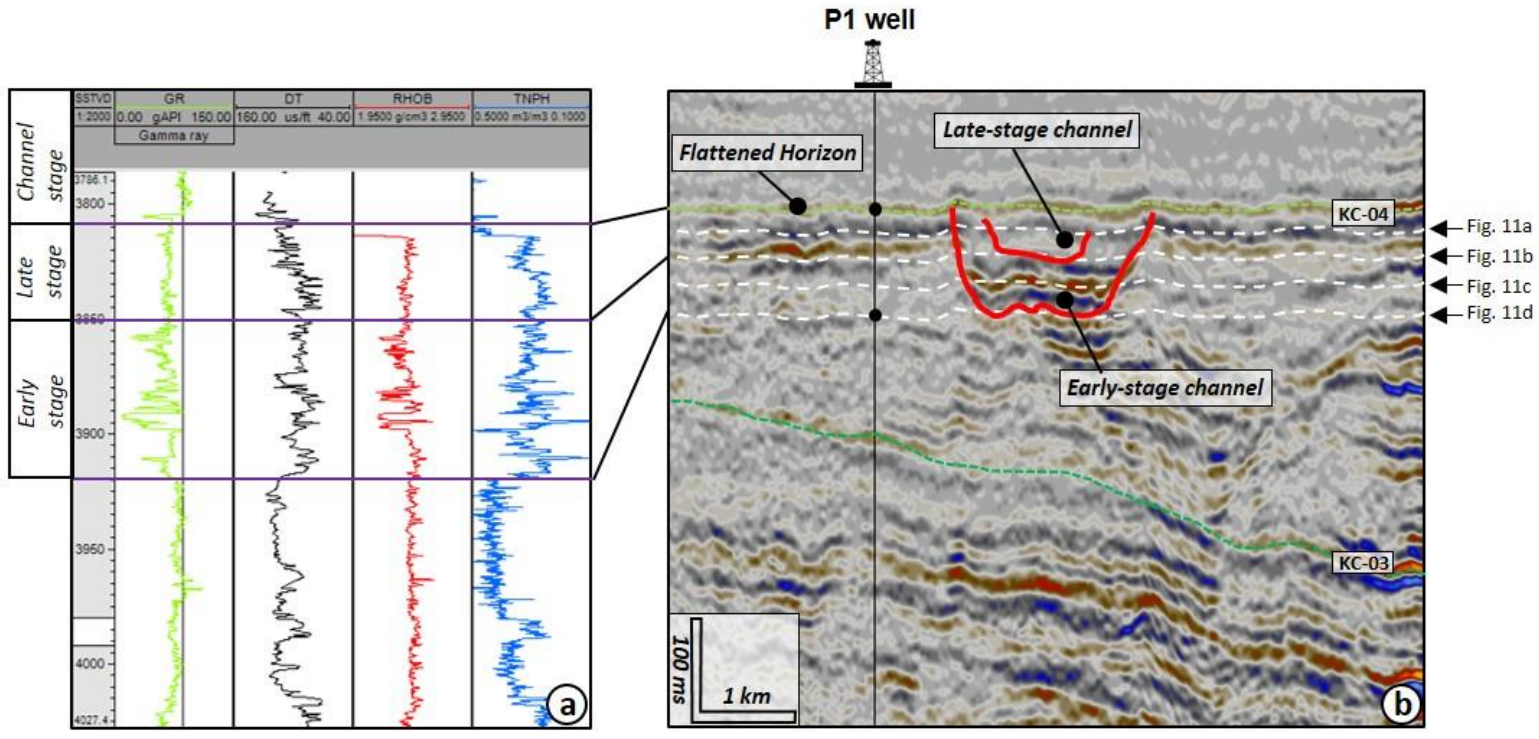

1066 Figure 8

1067

1068

1069

1070

1071

1072

1073

1074

1075

1076

1077

1078

1079

1080

1081

1082

1083

1084

1085 

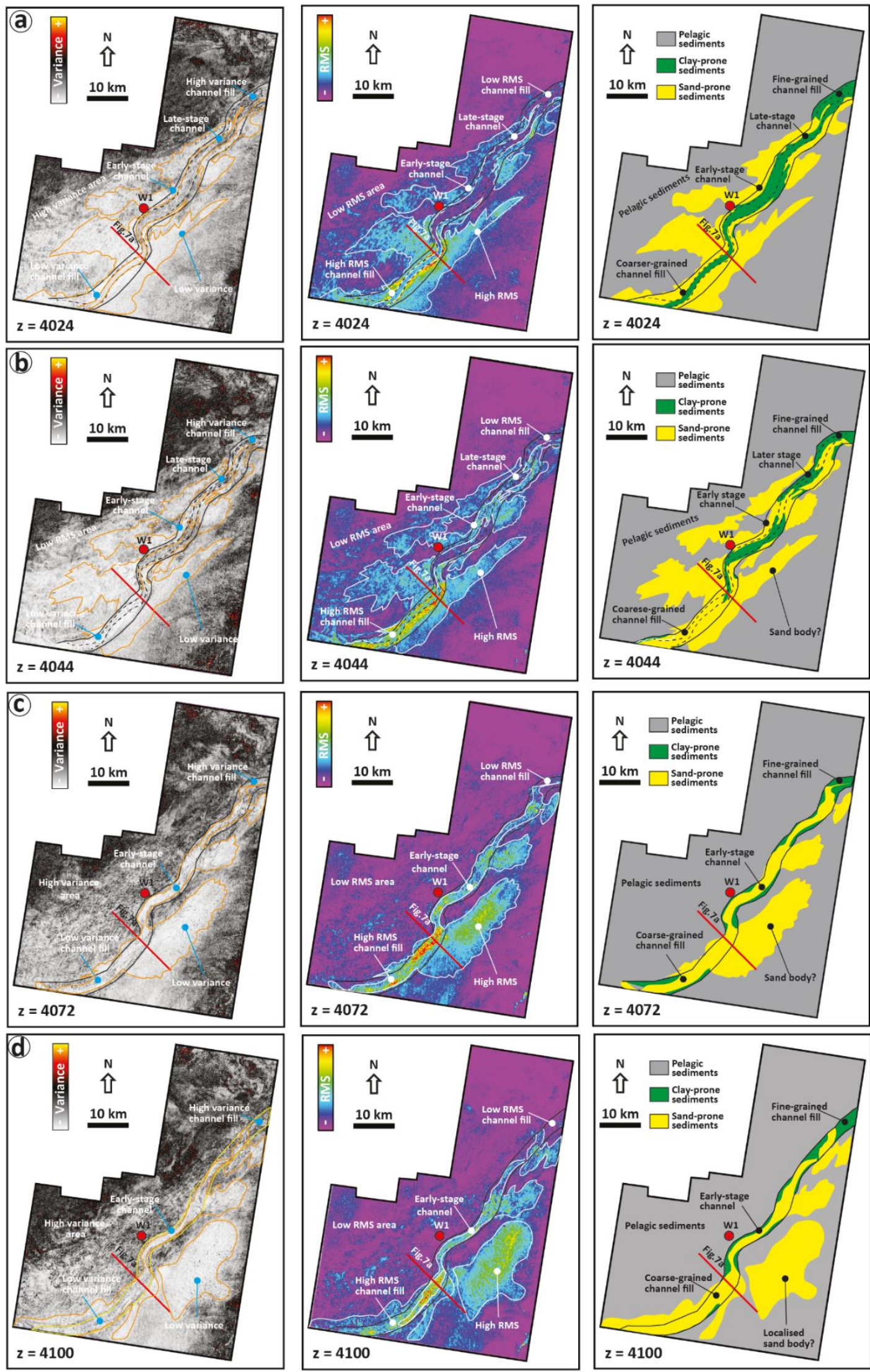

1087

1088

Figure 9 


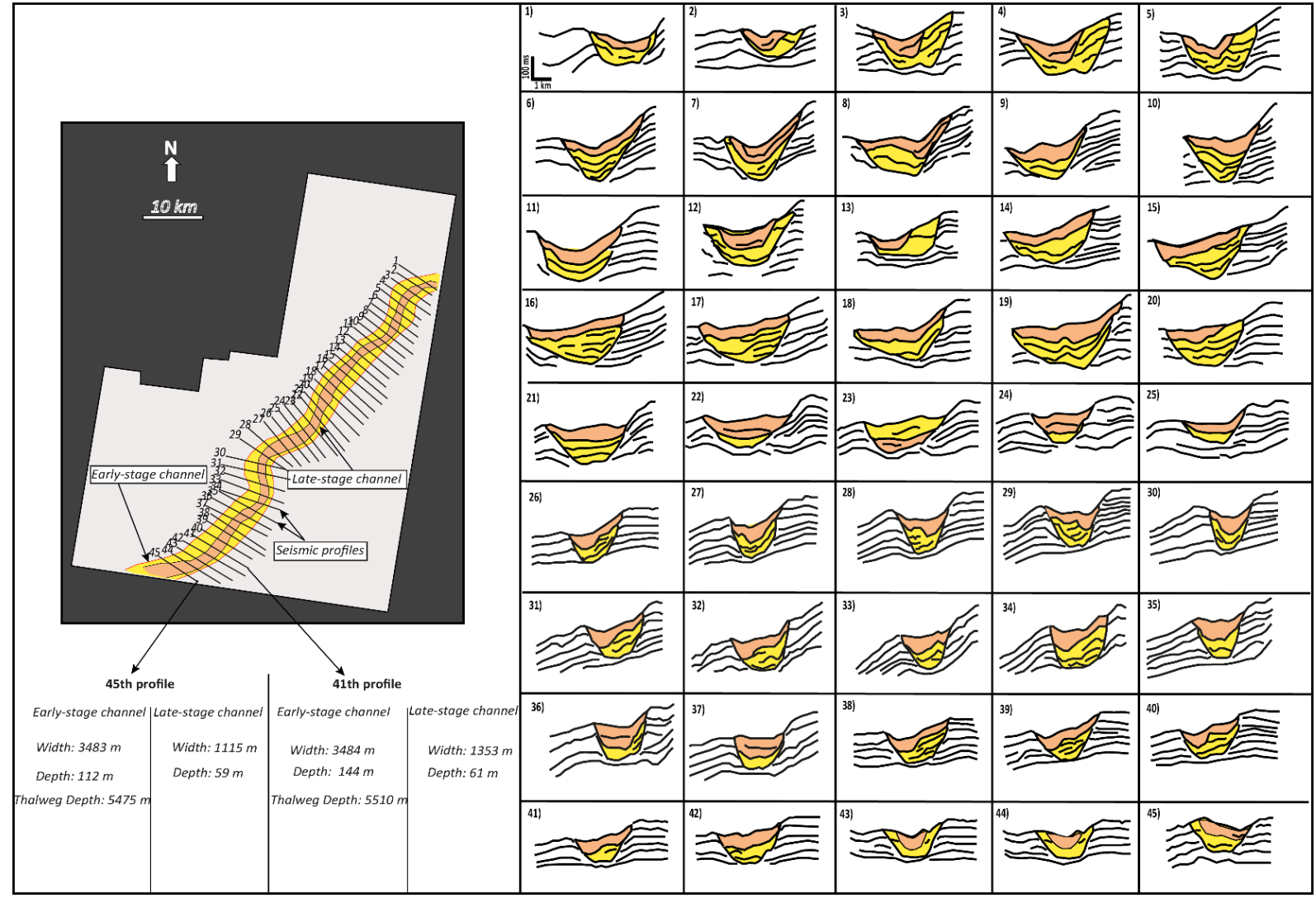

1091

1092 Figure 10

1093

1094

1095

1096

1097

1098

1099

1100

1101

1102

1103

1104

1105 


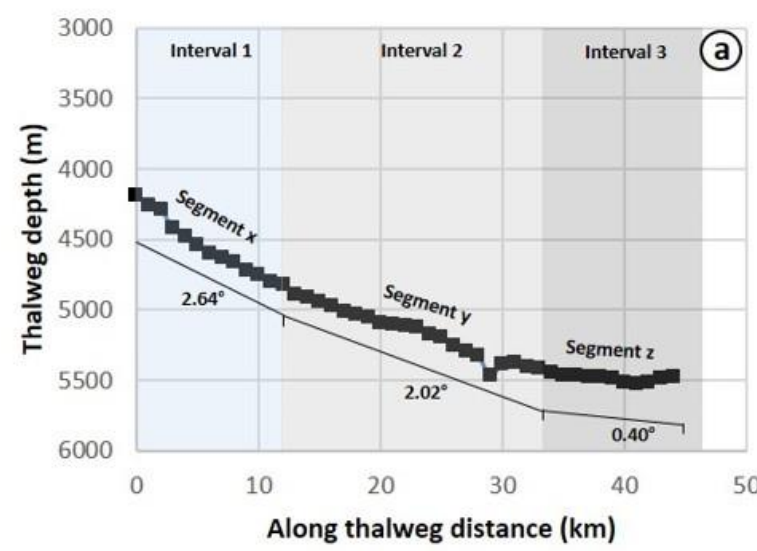

$\rightarrow$ Thalweg depth

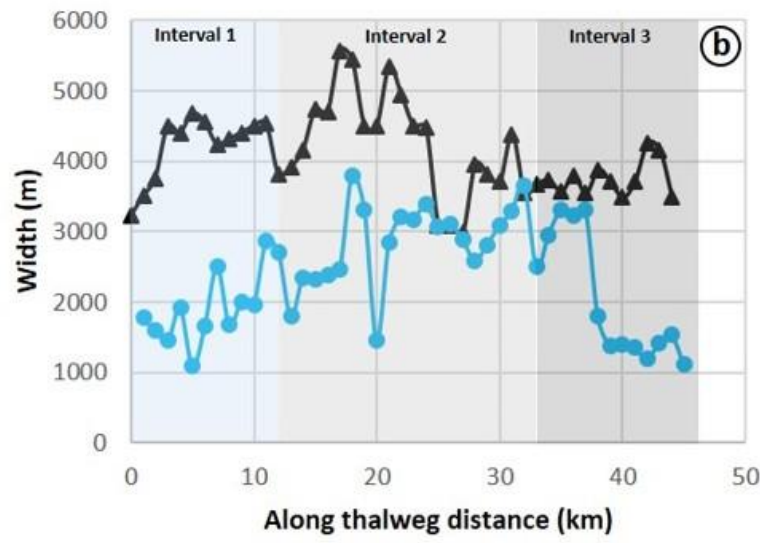

——Early-stage channel width

- - Late-stage channel width

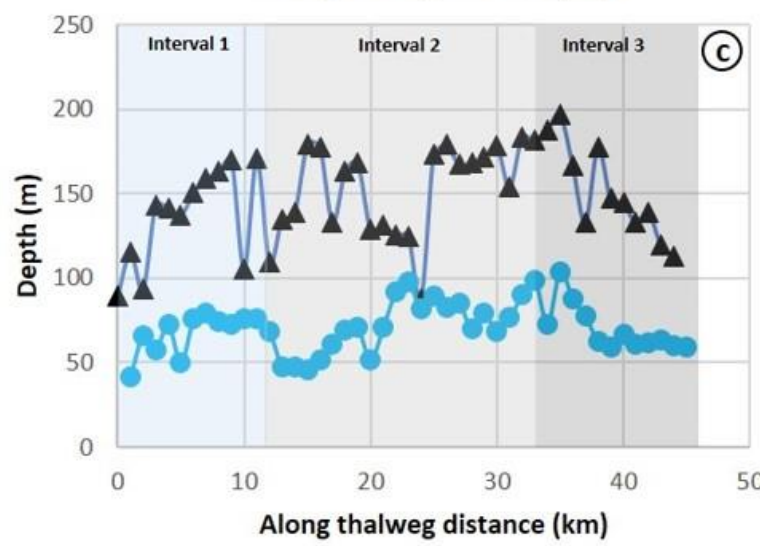

__ Early-stage channel depth

- Late-stage channel depth

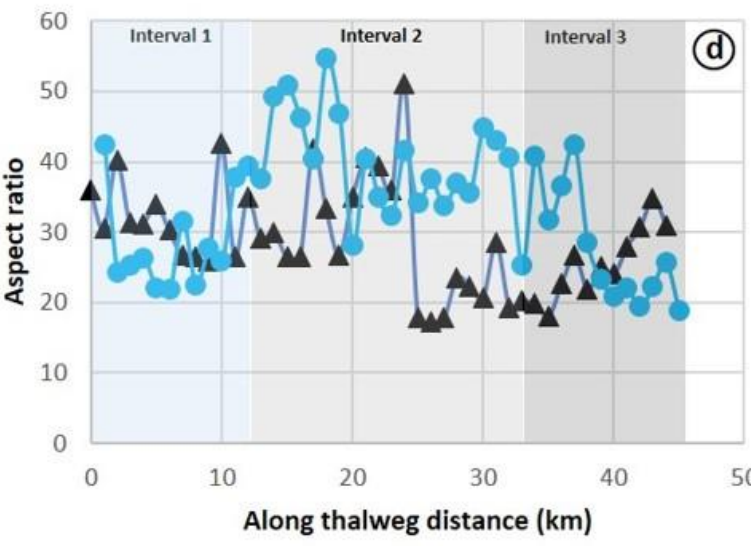

Early-stage channel Width/depth ratio

- Late-stage channel Width/depth ratio

Figure 11 

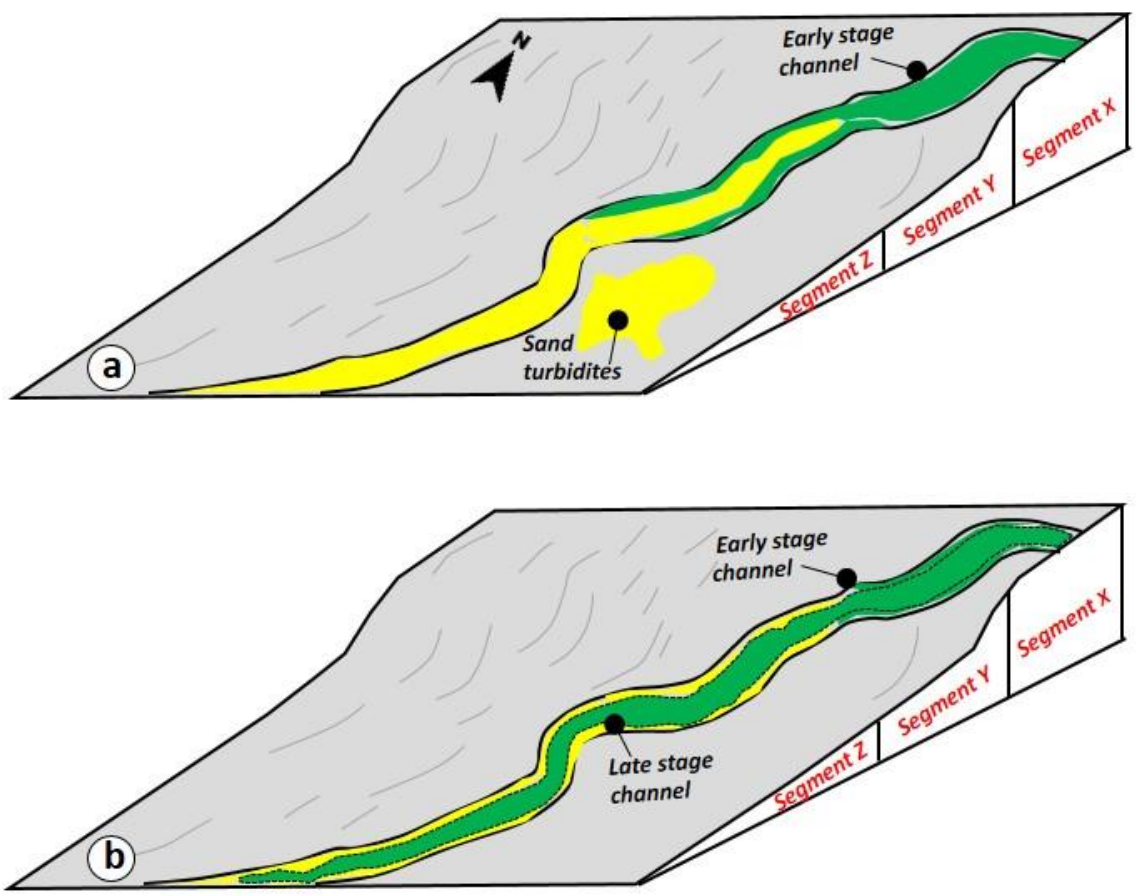

1110

Pelagics sediments Clay-prone sediments Sand-prone sediments

1111 Figure 12

1112

1113

1114

1115

1116

1117

1118

1119

1120

1121

1122

1123

1124

1125

1126 


\begin{tabular}{|c|c|c|c|c|c|}
\hline Seismic facies & Seismic profile & Schematic & Description & Plan/map view & Interpretation \\
\hline SF1 & & & $\begin{array}{l}\text { Chaotic, high amplitude, } \\
\text { discontinuous reflections, } \\
\text { basal lags usually confined } \\
\text { within a V- or U- shaped } \\
\text { erosional surface }\end{array}$ & & $\begin{array}{l}\text { Coarse-grained } \\
\text { channel fill }\end{array}$ \\
\hline SF2 & & & $\begin{array}{l}\text { Low to high amplitude, } \\
\text { discontinuous to chaotic } \\
\text { reflections, with a U- or V- } \\
\text { shaped external geometry }\end{array}$ & & $\begin{array}{l}\text { Fine-grained } \\
\text { Channel fill }\end{array}$ \\
\hline SF3 & & & $\begin{array}{l}\text { Semi transparent, low } \\
\text { amplitude, semi-continuous } \\
\text { to continuous reflections }\end{array}$ & & Pelagics sediments \\
\hline SF4 & tons & & $\begin{array}{l}\text { high- to low-amplitude, } \\
\text { continuous, parallel to } \\
\text { subparallel reflections }\end{array}$ & & Levee deposits \\
\hline SF5 & 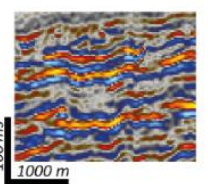 & & $\begin{array}{l}\text { High amplitude seismic facies } \\
\text { displaying an aggradational } \\
\text { pattern with parallel and } \\
\text { good continuity reflectors }\end{array}$ & & $\begin{array}{l}\text { Turbidites fan } \\
\text { system }\end{array}$ \\
\hline
\end{tabular}


1145 Table 2

1146

\begin{tabular}{|c|c|c|c|}
\hline & \multicolumn{3}{|c|}{ Downslope $\longrightarrow$} \\
\hline Measurements & $1(0-12$ km) & $2(12-33 \mathrm{~km})$ & $3(33-44 \mathrm{~km})$ \\
\hline Channel gradient $\left({ }^{\circ}\right)$ & 2.64 & 2.02 & 0.40 \\
\hline Thalweg depth (m) & $4188-4820$ & $4820-5463$ & 5417- 5522 \\
\hline $\begin{array}{l}\text { Early/Late stage } \\
\text { Channel width (m) }\end{array}$ & $3224-4677 / 1094-2865$ & $2879-5573 / 1452-3802$ & $3483-4260 / 1115-3300$ \\
\hline $\begin{array}{l}\text { Early/Late stage } \\
\text { Channel depth }(\mathrm{m})\end{array}$ & $89-171 / 41-79$ & $109-179 / 45-98$ & $112-197 / 59-103$ \\
\hline $\begin{array}{l}\text { Aspect Ratio } \\
\text { Early/Late Channel }\end{array}$ & $25-42 / 21-42$ & $26-51 / 25-54$ & $18-34 / 18-42$ \\
\hline
\end{tabular}

